NBER WORKING PAPER SERIES

\title{
SOVEREIGN DEBT STANDSTILLS
}

Juan C. Hatchondo

Leonardo Martinez

César Sosa-Padilla

Working Paper 28292

http://www.nber.org/papers/w28292

\author{
NATIONAL BUREAU OF ECONOMIC RESEARCH \\ 1050 Massachusetts Avenue \\ Cambridge, MA 02138 \\ December 2020, Revised July 2022
}

For their comments and suggestions we thank Javier Bianchi, Hal Cole, Max Dvorkin, Rob Johnson, Illenin Kondo, Zach Stangebye, and seminar participants at Notre Dame, IMF, Minneapolis Fed, University of Oklahoma, RedNIE, Virtual International Trade and Macroeconomics Seminar, the "Emerging and Frontier Markets: Capital Flows, Resiliency, Risks, and Growth" NBER Conference, the 2022 SED Annual Meeting, the 2021 CEBRA Annual Meeting, the 2021 Banco Central de Uruguay Annual Meeting, and the 2020 Richmond Fed Sovereign Debt Workshop. Remaining mistakes are our own. The views expressed herein are those of the authors and should not be attributed to the IMF, its Executive Board, its management, or the National Bureau of Economic Research.

NBER working papers are circulated for discussion and comment purposes. They have not been peer-reviewed or been subject to the review by the NBER Board of Directors that accompanies official NBER publications.

(C) 2020 by Juan C. Hatchondo, Leonardo Martinez, and César Sosa-Padilla. All rights reserved. Short sections of text, not to exceed two paragraphs, may be quoted without explicit permission provided that full credit, including $(\subset$ notice, is given to the source. 
Sovereign Debt Standstills

Juan C. Hatchondo, Leonardo Martinez, and César Sosa-Padilla

NBER Working Paper No. 28292

December 2020, Revised July 2022

JEL No. F34,F41

\section{ABSTRACT}

As a response to economic crises triggered by COVID-19, sovereign debt standstill proposals emphasize debt payment suspensions without write-offs on the face value of debt obligations. We quantify the effects of standstills using a standard default model. We find that a one-year standstill generates welfare gains for the sovereign equivalent to a permanent consumption increase of between $0.1 \%$ and $0.3 \%$, depending on the initial shock. However, except when it avoids a default, the standstill also implies capital losses for creditors of between $9 \%$ and $27 \%$, which is consistent with their reluctance to participate in these operations and indicates that this reluctance would persist even without a free-riding or holdout problem. We show that complementing the standstill with write-offs could reduce creditors' losses and simultaneously increase welfare gains. Our results cast doubts on the emphasis on standstills without a write-off.

Juan C. Hatchondo

Department of Economics

Social Science Centre Room 4071

London, Ontario, N6A 5C2

Canada

juanc.hatchondo@gmail.com

Leonardo Martinez

IMF Institute for Capacity Development

International Monetary Fund

700 19th St. NW

Washington DC 20431

leo14627@gmail.com
César Sosa-Padilla

Department of Economics

University of Notre Dame

3060 Jenkins Nanovic Hall

Notre Dame, IN 46556

and NBER

csosapad@nd.edu 


\section{Introduction}

As a response to COVID-19, the Group of 20 leading economies (G20) agreed to a temporary debt service standstill on bilateral official loan repayments from a group of 76 of the poorest countries. Other proposals emerged suggesting to extend standstills to private creditors and to other low and middle-income countries (Bolton et al., 2020). It is often emphasized that standstills should not be accompanied by write-offs (reductions in the face value of debt obligations) to avoid the perception of creditors' losses. ${ }^{1}$ This paper presents a quantitative evaluation of standstills that provide debt relief after the sovereign suffers a large shock. Our findings cast doubts on the emphasis of standstills without debt write-offs.

Motivated by recent proposals to extend standstills as a response to COVID-19, we focus on a model of private creditors calibrated to a typical emerging economy. We study a sovereign default model à la Eaton and Gersovitz (1981). Following Aguiar and Gopinath (2006) and Arellano (2008), this framework is commonly used for quantitative studies of sovereign debt crises. ${ }^{2}$ A small open economy receives a stochastic endowment stream of a single tradable good. At the beginning of each period, when the government is not in default, it decides whether to default on its long-term debt. A defaulting government faces an income cost and is temporarily prevented from issuing debt. Before the period ends, the government may change its debt positions, subject to the constraints imposed by its default decision. Bonds are priced by competitive foreign risk-neutral investors.

We evaluate the effects of a post-COVID-19 standstill by studying a suspension of debt payments after a negative endowment shock (the only shock in our stylized model) calibrated to mimic the effects of COVID-19 on the sovereign access to debt markets, as reflected in sovereign spreads (we also consider a more temporary shock to the mean endowment and that the sovereign is temporarily excluded from debt markets after the shock). ${ }^{3}$ We find that a debt standstill would produce welfare gains for the sovereign. However, except when the standstill avoids an imminent default, it would also produce capital losses (i.e., a decline in the market value of debt holdings) for creditors. For example, for a shock that increases sovereign spreads by 1,000 basis points, we find that a one-year standstill achieves a welfare gain for the sovereign equivalent to a permanent consumption increase of $0.3 \%$ but produces a capital loss of $21 \%$ for creditors. This is consistent with the creditors' reluctance to participate in standstills, and indicates that this reluctance would persist even without a free-riding or holdout problem.

Standstills generate capital losses because debt levels are higher after the standstill (because postponed payments earn interest). Even though the default probability is lower during the standstill, it is persistently higher

\footnotetext{
${ }^{1}$ Sovereign debt restructurings have also favored the postponement of payments over write-offs. Even before COVID-19, it was proposed to require standstills (or the "reprofiling" of debt payments) before the implementation of IMF programs and to include standstills triggered by liquidity shocks in sovereign bond covenants (Barkbu et al., 2012; Brooke et al., 2011; Buiter and Sibert, 1999; Consiglio and Zenios, 2015; IMF, 2017a; IMF, 2017b; Weber et al., 2011). Hatchondo et al. (2020c), Mallucci (2020), and Phan and Schwartzman (2020) study sovereign default models that allow for debt relief after a negative shock. This debt relief affects bond prices at the time bonds are issued. In contrast, motivated by current discussions, we study one-time unanticipated debt relief policies triggered by extraordinary circumstances.

${ }^{2}$ This model is also used in studies of household default (Athreya et al., 2007; Chatterjee et al., 2007; Hatchondo et al., 2015; Li and Sarte, 2006; Livshits et al., 2008).

${ }^{3}$ Arellano et al. (2020a) present a rich model of the COVID-19 pandemic and its effect on sovereign default risk. They study the effects of debt relief in the form new non-defaultable loans. We focus on the simpler standard default model and study standstills and write-offs.
} 
after the standstill, and even higher than it would have ever been without a standstill. Bondholders suffer capital losses because they are not properly compensated for the increase in the default probability not only of postponed payments but also on all other payments. Creditors' losses after a standstill may be significant because after large negative shocks, the price of debt becomes very sensitive to changes in the debt level. ${ }^{4}$

We find that write-offs tend to dominate standstills. Both policies provide effective debt relief and are beneficial to the sovereign. However, while write-offs achieve debt relief through a persistent decline in debt payments, standstills achieve debt relief only through a temporary reduction in debt payments and tend to generate higher default risk after the payment suspension is over. The higher expected default risk associated with standstills implies higer expected deadweight losses from defaults, which hurt the sovereign but do not benefit its creditors. Write-offs provide debt relief while reducing future default risk, and thus the expected deadweight losses from defaults, creating a surplus to be shared between the sovereign and creditors.

We show that when standstills are combined with write-offs, they can produce a Pareto improvement for the sovereign and creditors (as a group). For the example presented above, adding to the one-year standstill a debt write-off of $21 \%$, eliminates creditors' losses, while increasing the sovereign's gains from $0.3 \%$ to $0.8 \%$. Compared with the standstill without write-offs, adding to the standstill a write-off of $47 \%$ would increase the sovereign's gains to $1.8 \%$ without creating additional losses for creditors. Pareto gains from write-offs are larger when the economy is hit by a larger shock. For large enough shocks, write-offs may generate Pareto gains even without standstills. ${ }^{5}$ Overall, our results cast doubts on the emphasis on avoiding write-offs during standstills, and even more so after large shocks such as COVID-19.

\section{$1.1 \quad$ Related literature}

Since standstills are a form of debt maturity extension and debt relief can be thought of as debt restructuring, our results are related to those in studies of optimal maturity choices in debt restructurings. ${ }^{6}$ Aguiar et al. (2019) present a model in which it is optimal to shorten debt maturity in debt restructurings. Their result is explained by a time-inconsistency (debt dilution) problem that arises in default models with long-term debt (Arellano and Ramanarayanan, 2012; Chatterjee and Eyigungor, 2012, 2015; Hatchondo and Martinez, 2009; Hatchondo et al.,

\footnotetext{
${ }^{4}$ This is a standard feature of default models. While it is challenging to test empirically how the effect of debt on the bond price (or the sovereign spread) changes in crises, existing evidence is consistent with this feature. Jaramillo and Tejada (2011) document that the spread is more sensitive to increases in external public debt in countries without investment grade (which is correlated with higher spreads that are in turn correlated with lower levels of aggregate income). David et al. (2019) find the decline in spread after the announcement of fiscal consolidations is larger when the spread was already high prior to the announcement. Hatchondo et al. (2020a) document that the spread increases more with debt in years with high spread. Bi and Traum (2020) find a more significant effect of fiscal information on bond prices during crises. Gu and Stangebye (2018) present similar findings.

${ }^{5}$ The possibility of Pareto improvements in a situation of debt overhang due to the negative effect of debt on investment has long being recognized (Froot, 1989; Krugman, 1988a; Krugman, 1988b; Sachs, 1989). In this paper, there is a form of debt overhang even without investment, because a debt reduction (write-off) lowers default risk and thus increases the market value of debt claims. In Hatchondo et al. (2014), we show that this is consistent with changes in debt market values during debt restructuring episodes. Note that while introducing write-offs would benefit creditors as a group (and thus, creditors as a group would accept voluntarily these write-offs), this does not mean that individual creditors would accept these write-offs. This is because of the well-known free-riding or holdout problem (Wright, 2011).

${ }^{6}$ Arellano et al. (2022) document that countries typically exit restructurings with higher debt levels, as the sovereign exit standstills in our simulations.
} 
2020a, 2016; Sanchez et al., 2018): the government would like to commit to lower indebtedness and thus higher bond prices in the future because (with long-term debt) this would imply it can sell bonds at a higher price today. This problem is worse with longer-maturity debt. Therefore, (at the moment of the restructuring) it is optimal to choose shorter maturities.

Dvorkin et al. (2020) and Mihalache (2020) show that in spite of the government's time inconsistency problem, it is possible to account for the extensions of maturity in the restructurings data with a richer model in which: (i) there is risk of loosing access to debt markets, (ii) there is a regulatory cost of write-offs, and (iii) restructurings occur after the economy recovers from the shock that triggered the default. Our analysis differs from theirs in several dimensions: difficulties in market access in our exercises are given by the endogenous borrowing constraint, we do not consider a regulatory cost of write-offs, and we focus on preventive debt relief at the moment the economy is hit by an adverse shock. Furthermore, Aguiar et al. (2019), Dvorkin et al. (2020), and Mihalache (2020) model the bargaining between creditors and the government and focus on restructurings that do not generate capital losses for creditors. We evaluate standstill proposals that could generate losses for creditors and study how the outcomes of these proposals could be improved with write-offs. ${ }^{7}$

We show that write-offs tend to be superior to standstills, which is consistent with the findings of Aguiar et al. (2019), Dvorkin et al. (2020), and Mihalache (2020). However, the mechanism behind our findings is somewhat different from the overindebtedness due to time inconsistency they highlight. We show that debt issuances are not significant during the standstill, but debt still increases because it is automatically rolled over. This distinction is important, because while limiting borrowing through conditionality or fiscal rules (Hatchondo et al., 2020b) mitigates the time inconsistency problem emphasized by Aguiar et al. (2019), Dvorkin et al. (2020), and Mihalache (2020), it would not mitigate the shortcomings of standstills (because debt issuances are not significant during standstills). In our model, the relief implied by the standstill is short-lived, and market access conditions are not favorable when the government needs to start rolling over debt after the standstill (in part because of higher debt levels due to the standstill). Therefore, the government does not want to issue debt during the standstill.

Instead of the time inconsistency problem underscored in previous studies, we emphasize that standstills and write-offs move indebtedness in the opposite direction. Standstills increase indebtedness, and thus tend to increase the default probability and the expected deadweight losses from defaults. In turn, the higher default probabilities create losses for creditors. In contrast, write-offs lower indebtedness, and thus tend to lower expected deadweight losses from defaults, and to create gains for creditors. Moreover, the combination of negative shocks and standstills generates opportunities for Pareto gains from write-offs. To the extent that the reluctance to use write-offs is due to regulation (Dvorkin et al., 2020) or to focus on payment suspensions in the doctrine of necessity (Bolton et al., 2020), our results indicate that the inefficiencies implied by these legal frameworks are significant.

\footnotetext{
${ }^{7}$ Analyzing why creditors (including official creditors and multilateral organizations) could accept capital losses (or how losses could be imposed to private creditors, for instance, through financial repression) is beyond the scope of this paper. Bolton et al. (2020) explain that the "doctrine of necessity" in public international law recognizes that sovereigns may sometimes need to respond to exceptional circumstances that are unforeseen, unpredictable, and unavoidable, by suspending the normal performance of their contractual obligations.
} 
Furthermore, while our results on the advantages of write-offs over standstills are consistent with the findings against maturity extensions, we show that losses from adding standstills to the write-off are not significant for large-enough write-offs.

The rest of the article proceeds as follows. Section 2 introduces the model. Section 3 presents the results. Section 4 concludes.

\section{The model}

We present the simplest version of the default model with long-term debt and a standard calibration.

\section{$2.1 \quad$ Environment}

The government has preferences given by

$$
\mathbb{E}_{t} \sum_{j=t}^{\infty} \beta^{j-t} u\left(c_{j}\right),
$$

where $\mathbb{E}$ denotes the expectation operator, $\beta$ denotes the subjective discount factor, and $c_{t}$ represents consumption of private agents. The utility function is strictly increasing and concave. The government cannot commit to future (default and borrowing) decisions.

The timing of events within each period is as follows. First, the government learns the economy's income. After that, the government chooses whether to default on its debt. Before the period ends, the government may change its debt positions, subject to the constraints imposed by its default decision.

The economy's endowment of the single tradable good is denoted by $y \in Y \subset \mathbb{R}_{++}$. This endowment follows a Markov process.

As Arellano and Ramanarayanan (2012) and Hatchondo and Martinez (2009), we assume a bond issued in period $t$ promises an infinite stream of coupons, decreasing at a constant rate $\delta$. Hence, debt dynamics can be represented as follows:

$$
b_{t+1}=(1-\delta) b_{t}+l_{t}
$$

where $b_{t}$ is the number of coupons due at the beginning of period $t$, and $l_{t}$ is the number of long-term bonds issued in period $t$. Bonds are priced in a competitive market inhabited by a large number of risk-neutral foreign investors that discount future payoffs at the risk-free rate, $r$.

When the government defaults, it does so on all current and future debt obligations. A default event triggers exclusion from the debt market for a stochastic number of periods. Furthermore, income is given by $y-\phi(y)$ in every period in which the government is excluded from debt markets. Starting the first period after the default period, with a constant probability $\psi \in[0,1]$, the government may regain access to debt markets. The government exits default without debt (Appendix A shows that our findings are robust to relaxing this standard assumption 
in the literature).

\subsection{Recursive formulation}

Let $b$ denote the number of outstanding coupon claims at the beginning of the current period, and $b^{\prime}$ denote the number of outstanding coupon claims at the beginning of the next period. Let $d$ denote the current-period default decision. We assume that $d$ is equal to 1 if the government defaulted in the current period and is equal to 0 if it did not. Let $V$ denote the government's value function at the beginning of a period, that is, before the default decision is made. Let $V_{0}$ denote the value function of a sovereign not in default. Let $V_{1}$ denote the value function of a sovereign in default. Let $F$ denote the conditional cumulative distribution function of the next-period endowment $y^{\prime}$. For any bond price function $q$, the function $V$ satisfies the following functional equation:

$$
V(b, y)=\max _{d \epsilon\{0,1\}}\left\{d V_{1}(y)+(1-d) V_{0}(b, y)\right\}
$$

where

$$
V_{1}(y)=u(y-\phi(y))+\beta \int\left[\psi V\left(0, y^{\prime}\right)+(1-\psi) V_{1}\left(y^{\prime}\right)\right] F\left(d y^{\prime} \mid y\right)
$$

and

$$
V_{0}(b, y)=\max _{b^{\prime} \geq 0}\left\{u\left(y-b+q\left(b^{\prime}, y\right)\left[b^{\prime}-(1-\delta) b\right]\right)+\beta \int V\left(b^{\prime}, y^{\prime}\right) F\left(d y^{\prime} \mid y\right)\right\} .
$$

The bond price is given by the following functional equation:

$$
q\left(b^{\prime}, y\right)=\frac{1}{1+r} \int\left[1-\hat{d}\left(b^{\prime}, y^{\prime}\right)\right] F\left(d y^{\prime} \mid y\right)+\frac{1-\delta}{1+r} \int\left[1-\hat{d}\left(b^{\prime}, y^{\prime}\right)\right] q\left(\hat{b}\left(b^{\prime}, y^{\prime}\right), y^{\prime}\right) F\left(d y^{\prime} \mid y\right)
$$

where $\hat{d}$ and $\hat{b}$ denote the future default and borrowing rules that lenders expect the government to follow. The default rule $\hat{d}$ is equal to 1 if the government defaults, and is equal to 0 otherwise. The function $\hat{b}$ determines the number of coupons that will mature next period.

\subsection{Equilibrium definition}

A Markov Perfect Equilibrium is characterized by

1. a default rule $\hat{d}$ and a borrowing rule $\hat{b}$,

2. a bond price function $q$,

such that: 
Table 1: Benchmark parameter values.

\begin{tabular}{lccc}
\hline \hline Risk aversion & $\gamma$ & 2 & Standard \\
Risk-free rate & $r$ & $1 \%$ & Standard \\
Discount factor & $\beta$ & 0.9745 & Standard \\
Probability default ends & $\psi$ & 0.083 & $\mathbb{E}$ (exclusion) $=3$ years \\
Debt duration & $\delta$ & 0.033 & Debt duration $=5$ years \\
Income autocorrelation coefficient & $\rho$ & 0.94 & Mexico GDP \\
Standard deviation of innovations & $\sigma_{\epsilon}$ & $1.5 \%$ & Mexico GDP \\
Mean log income & $\mu$ & $(-1 / 2) \sigma_{\epsilon}^{2}$ & Mexico GDP \\
\hline \multicolumn{4}{c}{ Calibrated to match targets } \\
Income cost of defaulting & $\lambda_{0}$ & 0.183 & Average debt $=44 \%$ \\
Income cost of defaulting & $\lambda_{1}$ & 1.343 & Average spread $=3.4 \%$ \\
\hline \hline
\end{tabular}

(a) given $\hat{d}$ and $\hat{b}$, the bond price function $q$ is given by equation (4); and

(b) the default rule $\hat{d}$ and borrowing rule $\hat{b}$ solve the dynamic programming problem defined by equations (1)-(3), when the government can trade bonds at $q$.

\subsection{Calibration}

We use the standard calibration presented by Hatchondo and Martinez (2017). The utility function displays a constant coefficient of relative risk aversion, i.e.,

$$
u(c)=\frac{c^{1-\gamma}-1}{1-\gamma}, \text { with } \gamma \neq 1
$$

The endowment process follows:

$$
\log \left(y_{t}\right)=(1-\rho) \mu+\rho \log \left(y_{t-1}\right)+\varepsilon_{t}
$$

with $|\rho|<1$, and $\varepsilon_{t} \sim N\left(0, \sigma_{\epsilon}^{2}\right)$. As in Chatterjee and Eyigungor (2012), we assume a quadratic loss function for income during a default episode $\phi(y)=\max \left\{y\left[\lambda_{0}+\lambda_{1}[y-\mathbb{E}(y)]\right], 0\right\}$.

Table 1 presents the benchmark values given to all parameters in the model. A period in the model refers to a quarter. The coefficient of relative risk aversion, the risk-free interest rate, and the discount factor $\beta$ take standard values. We assume an average duration of sovereign default events of three years $(\psi=0.083)$, following Dias and Richmond (2007).

For choosing the parameters that govern the endowment process, the level and duration of debt, and the mean spread, the calibration uses data from Mexico, a common reference for studies on emerging economies (Mexico display the same properties that are observed in other emerging economies; see Aguiar and Gopinath, 2007; Neumeyer and Perri, 2005; and Uribe and Yue, 2006). While the G20 standstill proposal targets low- 
income countries, other proposals suggest extending standstills to middle-income countries (Bolton et al., 2020). Furthermore, the objective of this paper is not to discuss the G20 standstill proposal but to underscore the merits of considering haircuts more generally when thinking about debt relief as a response of the economic costs of COVID-19 (including, for example, for emerging markets' debt restructurings). Note also that the calibration of default models is based on matching the mean levels of debt and spread in the data (Hatchondo and Martinez, 2017), and these levels for Mexico are within the range of those observed for low-income countries. Other parameters for Mexico, such as those that govern the endowment process, are also similar to those of low-income countries.

Unless we explain otherwise, we compare simulation results with data from Mexico from the first quarter of 1980 to the fourth quarter of 2011. The parameter values that govern the endowment process are chosen to mimic the behavior of GDP in Mexico during that period.

We set $\delta=3.3 \%$. With this value and our target for the average spread, bonds have an average duration of 5 years in the simulations, which is roughly the average debt duration observed in Mexico according to Cruces et al. (2002). The parameters of the income cost of defaulting $\lambda_{0}$ and $\lambda_{1}$ are calibrated targeting an average debt-to-GDP ratio of 44 percent and a mean spread of 3.4 percent. We solve the model using value function iteration and interpolation (Hatchondo et al., 2010).

\subsection{Simulations}

Table 2 shows that the model simulations match the targeted levels of debt and spread. The model also does a good job in mimicking other non-targeted moments.

\subsection{The shock}

The main purpose of this paper is to present a quantitative evaluation of proposals to use a sovereign debt standstill to mitigate the economic effects of large negative shocks (like COVID-19). The only shock in our stylized model is a shock to the endowment. The key for evaluating the benefits of a standstill is how the shock impacts the government's access to debt markets, which is reflected in the sovereign spread. Thus, we study debt relief after the economy suffers a large endowment shock that produces a sizable increase in the sovereign spread.

We focus on an economy that starts with debt and endowment levels equal to the respective mean values in the simulations, and is hit with one of three possible endowment shocks. The "small" shock is such that the sovereign spread increases by 250 basis points $(y=0.9681)$, which is consistent with the increase of the Emerging Market Bond Index (EMBI) spread between December 2019 and April 2020 in Mexico and other economies that preserved market access after COVID-19. The "large" shock is such that the spread increases by 1000 basis points $(y=0.9475)$. This represents the shock faced by sub-investment grade borrowers that had more difficulties accessing debt markets after COVID-19. For example, in Sub-Saharan Africa, sovereign spreads increased 1,000 
Table 2: Business Cycle Statistics

\begin{tabular}{lcc}
\hline \hline \multicolumn{3}{c}{ Targeted moments } \\
& Model & Data \\
Mean Debt-to-GDP & 44 & 44 \\
Mean spread $\left(r_{s}\right)$ & 3.4 & 3.4 \\
\hline \multicolumn{3}{c}{ Non-Targeted moments } \\
$\sigma(c) / \sigma(y)$ & 1.4 & 1.2 \\
$\sigma(t b)$ & 0.8 & 1.4 \\
$\sigma\left(r_{s}\right)$ & 1.5 & 1.5 \\
$\rho(t b, y)$ & -0.8 & -0.7 \\
$\rho(c, y)$ & 0.99 & 0.93 \\
$\rho\left(r_{s}, y\right)$ & -0.7 & -0.5 \\
$\rho\left(r_{s}, t b\right)$ & 0.9 & 0.6 \\
\hline \hline
\end{tabular}

Note: Debt levels in the simulations are calculated as the present value of future payment obligations discounted at the risk-free rate $\left(b(1+r)(\delta+r)^{-1}\right)$ and reported as a percentage of annualized income. The standard deviation of $x$ is denoted by $\sigma(x)$. The coefficient of correlation between $x$ and $z$ is denoted by $\rho(x, z)$. Moments are computed using detrended series. Trends are computed using the Hodrick-Prescott filter with a smoothing parameter of 1,600 . Moments for the simulations correspond to the mean value of each moment in 250 simulation samples, with each sample including 120 periods (30 years) without a default episode. Simulation samples start at least five years after a default. Default episodes are excluded to improve comparability with the data. Consumption and income are expressed in logs.

basis points, on average, with COVID-19 (IMF, 2020). The "default-inducing" shock is the smallest shock that would trigger a default $(y=0.934)$ and that is such that a standstill would prevent the default. ${ }^{8}$

\subsection{Standstills}

A standstill consists of the following:

1. The period of the shock, lenders and the government enter in a debt standstill agreement that lasts for $T^{D S}$ periods, unless a default is declared during the standstill, in which case, the default ends the standstill.

2. During each standstill period, the government is exempt from making debt payments and the stock of debt grows at the rate $r^{D S}$.

3. The government can issue debt during the standstill, and as the payments of pre-standstill debt, new debt payments start after the standstill is over (this allows us to analyze standstills without incorporating different debt instruments and thus additional endogenous state variables). We do not find significant debt issuances during standstills.

\footnotetext{
${ }^{8}$ There is a narrow set of income levels for which the government would choose to default without a standstill but would choose to repay with a standstill (between 0.9207 and 0.934 for a one-year standstill).
} 
We assume that $r^{D S}=1.85 \%$, which is equal to the risk-free rate plus the average (quarterly) spread. This assumption is consistent with the stated intention of implementing standstills that do not produce losses to creditors in present value terms. Analyzing different values of $r^{D S}$ is equivalent to introducing write-offs in the present value of debt claims.

\section{Results}

This section evaluates the effects of standstills after the economy suffers an adverse income shock. We show first that standstills generate welfare gains for the sovereign and tend to generate losses for creditors. Then, we show that debt write-offs dominate standstills.

\subsection{Effects of a debt standstill}

The top row of Figure 1 illustrates the market value of debt claims, measured as the expected present discounted value of coupon obligations. The expectation takes into account default risk. Namely, the market value of debt claims in the benchmark economy is measured as

$$
M V(b, y)=b[1-\hat{d}(b, y)][1+(1-\delta) q(\hat{b}(b, y), y)]
$$

This is the market value at which debt holders could sell the debt stock at the beginning of the period.

Similarly, the market value of debt claims with a standstill is measured as

$$
M V^{D S_{j}}(b, y)=b\left[1-\hat{d}^{D S_{j}}(b, y)\right]\left(1+r^{D S}\right) q^{D S_{j}}\left(\hat{b}^{D S_{j}}(b, y), y\right)
$$

where $\hat{d}^{D S_{j}}, \hat{q}^{D S_{j}}$, and $\hat{b}^{D S_{j}}$ denote the equilibrium default rule, bond price schedule, and borrowing rule in period $j$ of the debt standstill, respectively.

Figure 1 shows that for most debt ratios in the range of 20-50 percent of mean GDP, a standstill lowers the market value, and the longer the standstill, the higher the drop in market value. This occurs because the postponed debt payments lead to higher future debt and, therefore, higher future default probabilities. A more prolonged standstill helps to build up more debt and further increases future default probabilities.

Figure 1 also illustrates the "debt Laffer curve": the market value of debt is hump-shaped in debt. The market value initially increases with the debt stock until a point in which additional debt produces a large enough decline in bond prices (because of higher default probabilities). As illustrated in the bottom row of Figure 1, for higher debt levels, bond prices tend to decrease more sharply with an increase in the debt level. Furthermore, the top row of Figure 1 illustrates that the maximum market value decreases with the shocks and the standstill duration. This implies that after an adverse shock and with a longer standstill, it is more likely that the initial debt stock is on the decreasing region of the debt Laffer curve. 
(a) Small income shock
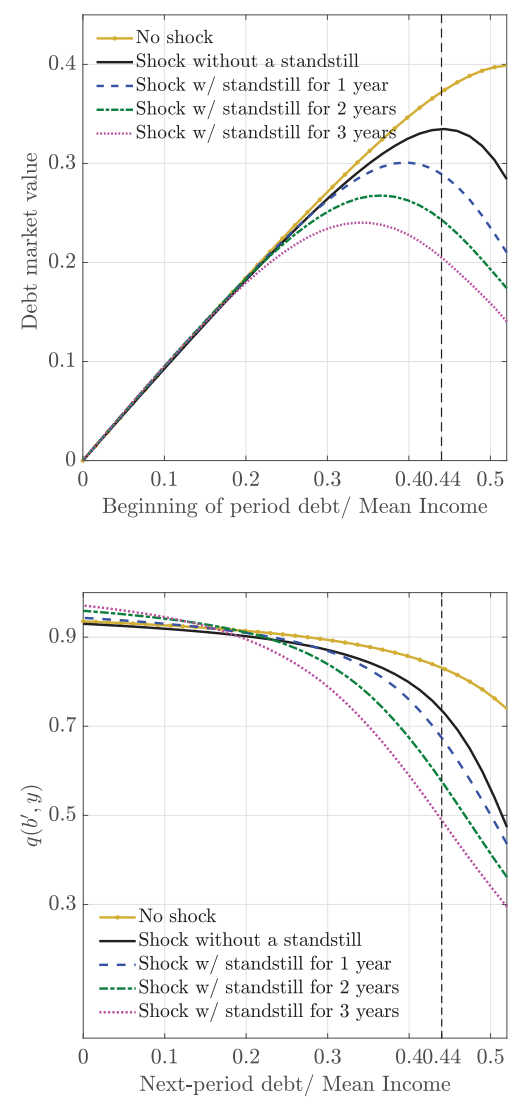

(b) Large income shock
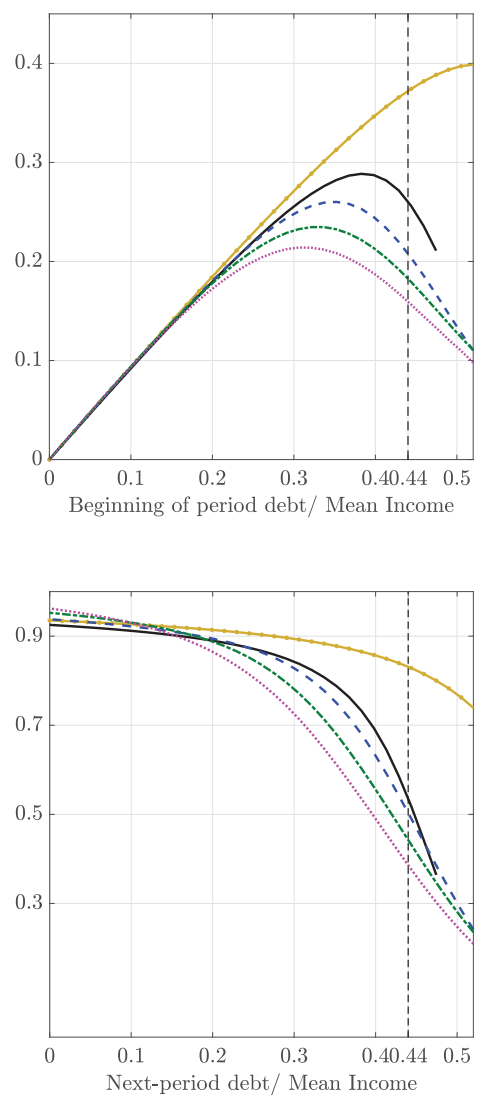

(c) Default-inducing income shock
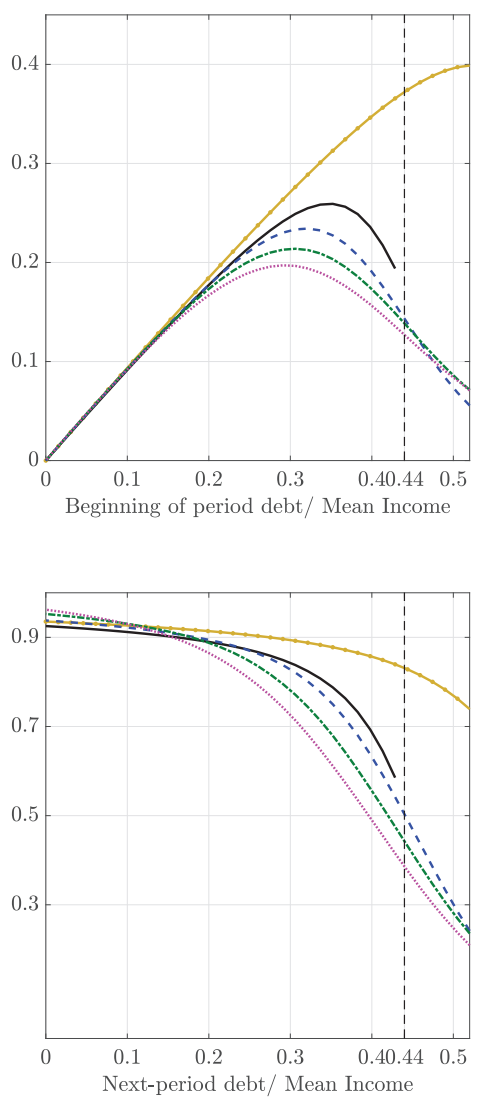

Figure 1: Debt market value and debt price. The dashed vertical line marks the initial debt level. A small (large) income shock increases the spread by 250 (1000) basis points starting from the average debt in the simulations. The default-inducing shock is the lowest income drop that triggers a default.

Figure 2 summarizes the welfare effects for creditors and the sovereign of introducing a standstill. We consider standstill durations from one to three years. The horizontal axis measures the loss in the market value of debt after the introduction of a standstill. Given that lenders are risk-neutral, this measure captures the welfare loss accrued to creditors. The vertical axis measures the welfare gain for the sovereign, in terms of the permanent change in equivalent consumption.

As expected, the sovereign enjoys welfare gains from the standstill and these gains increase with the standstill duration. The government gains from a standstill for two reasons. Firstly, the expected discounted value - for the sovereign - of servicing the postponed payments declines. Even though the postponed coupon payments accrue an interest of $r^{D S}$, the assumption that $\beta\left(1+r^{D S}\right)<1$ implies the sovereign discounts delayed payments more heavily than the rate at which delayed payments grow. Secondly, since standstills increase debt levels (dotted-red line in the middle-left panel of Figure 4), the payments that were due during the standstill are replaced by future payments with a higher default probability (middle-right panel of Figure 4). Since creditors are not properly 
(a) Small income shock

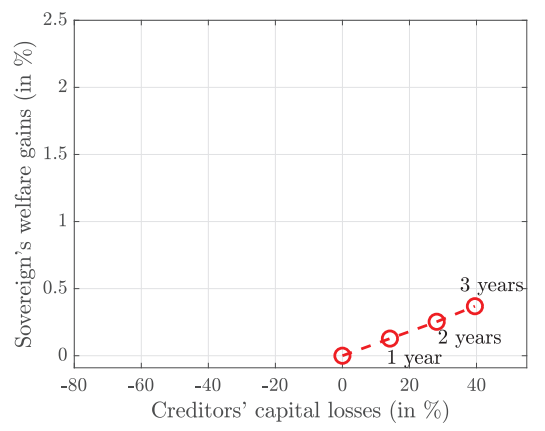

(c) Large income shock

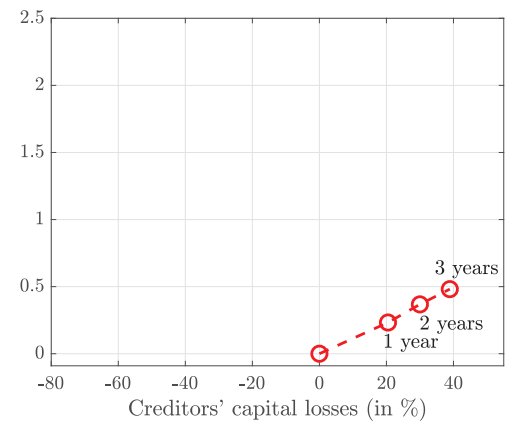

(c) Default-inducing income shock

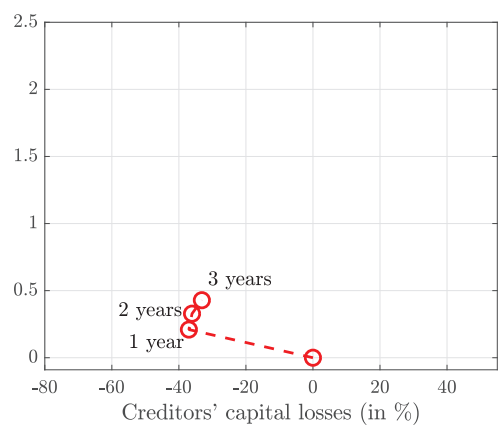

Figure 2: Sovereign's welfare gains and creditors' capital losses from introducing a standstill. Welfare gains are measured as the equivalent per-period permanent consumption increase. Creditors' capital losses are measured as in equations (5)-(6).

compensated for the higher default probability of these future payments, the sovereign benefits because it pays less of that extra debt in expectation. ${ }^{9}$ Appendix B offers an analytical characterization of the welfare effects of a standstill in a two-period environment.

Figure 2 also shows that a standstill generates capital gains for creditors only if it avert an imminent default. If the standstill does not prevent a default, lower default probabilities during the standstill are offset by higher default probabilities after the standstill (middle-right panel of Figure 4). Thus, in present value, a standstill entails a net transfer from creditors to the sovereign. Creditors' losses underscore a possible limitation of standstill proposals. While a standstill would benefit the sovereign, it may be difficult to convince private creditors to accept the standstill, even without considering free-riding or holdout problems.

\section{$3.2 \quad$ Standstills vs. write-offs}

The previous subsection established that standstills can produce welfare gains for the sovereign but at the same time they produce capital losses for creditors (except when they avoid a default). Following existing proposals we assumed that there is no write-off in the face value of sovereign debt. In this subsection, we focus on the possibility of combining standstills with write-offs (a reduction of the nominal level of the sovereign's indebtedness). After a write-off of $\theta$ in period $t$, the profile of debt obligations becomes $\left\{b_{t}(1-\theta), b_{t}(1-\delta)(1-\theta), b_{t}(1-\delta)^{2}(1-\theta), \ldots\right\}$. We show that debt write-offs dominate standstills.

Figure 3 presents the welfare effects of standstills accompanied by write-offs and of write-offs without any payment suspension. The marked solid curves show that write-offs can enhance standstills by generating larger welfare gains for the sovereign and lower creditors' capital losses. The figure also shows that write-offs alone dominate any combination of standstills with write-offs.

Why could write-offs be more efficient than standstills for providing debt relief? There are two mechanisms

\footnotetext{
${ }^{9}$ The sovereign incurs higher default costs as it defaults more often, but given that the default decision is strategic, the extra "savings" on future unpaid debt offsets the additional costs of defaulting.
} 
(a) Small income shock

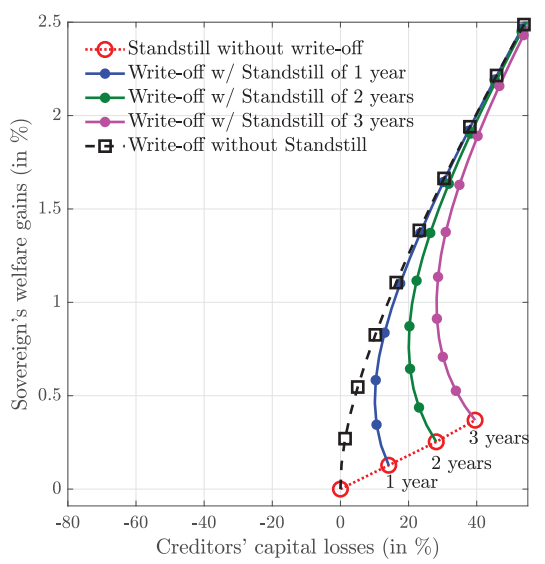

(b) Large income shock

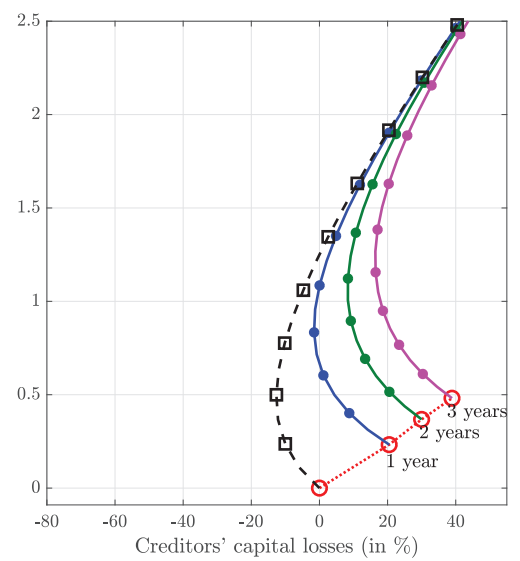

(c) Default-inducing income shock

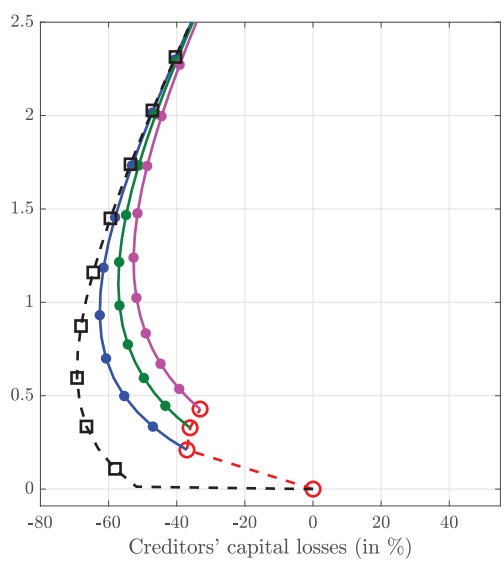

Figure 3: Sovereign's welfare gains and creditors' capital losses from implementing debt write-offs. The red curve corresponds to standstills without write-offs. In the other curves, from bottom to top, each mark represents an increase in the fraction of debt written off of $7 \%$. Curves representing the effects of write-offs combined with standstills start at the corresponding intersect with the standstill curve without write-off.

that can account for this result (see also Proposition 5 in Appendix B). Firstly, in contrast with standstills, by lowering debt and thus default probabilities, write-offs reduce the expected deadweight costs of defaulting, expanding the set of possible surpluses to be shared between the sovereign and its creditors. ${ }^{10}$ Note that as illustrated in Figure 3, for any standstill, there is a write-off that leaves creditors indifferent between writing off debt and offering the standstill. The lower default probabilities with the write-off implies lower expected deadweight costs of defaulting and thus higher sovereign welfare. Secondly, by lowering future debt, write-offs improve current borrowing opportunities. When the improvement is significant, the sovereign can even attain higher consumption in the short run with a write-off (Figure 4).

Note, however, that one potential disadvantage of write-offs compared with standstills is that in the short-run, with only a write-off, the sovereign keeps making payments that it would not make under a standstill. But if the sovereign is sufficiently patient, the future savings on deadweight costs of defaulting outweigh the possible short-run consumption decline implied by debt payments, and write-offs dominate standstills (Proposition 5 in Appendix B).

Figure 3 also shows that while write-offs appear superior to standstills, losses from combining write-offs with a standstill are not always significant, and are less significant for debt reliefs that include large write-offs. Consider the large shock (middle panel) and the one-year standstill, which without write-offs would trigger a $21 \%$ capital loss. For this loss, the inefficiency of combining write-offs with a one-year standstill is negligible: almost the same welfare gain can be obtained with either a $47.3 \%$ write-off alone or combining a $47.1 \%$ write-off with a one-year standstill. This occurs because for the low debt levels implied by such large write-offs, the standstill

\footnotetext{
${ }^{10}$ Recall that there is an inefficiency associated with defaults: the sovereign suffers costs that do not benefit lenders.
} 
is not expected to produce a significant increase in indebtedness (Figure 4), and therefore, standstills do not produce significant inefficiencies in the debt relief.

\subsection{Debt overhang}

The relative benefits of a write-off are magnified when standstills trigger a form of sovereign debt overhang and write-offs can simultaneously produce sovereign welfare gains and creditors' capital gains. In these situations, a write-off benefits creditors by increasing the probability of repayment and, thus, the market value of their debt holdings. ${ }^{11}$ As illustrated in the top panels of Figure 1, debt overhangs are more likely to occur with standstills and after large shocks. Note however, that as discussed in the previous subsection and in Appendix B, write-offs dominate standstills even without a debt overhang.

While write-offs are often referred to as a measure of creditors' losses, our analysis illustrates that write-offs are a measure of debt relief for the sovereign, but could produce (capital) gains for creditors. Let us focus on the large shock combined with a one-year standstill in Figure 3. There is an agreement zone for write-offs up to 21\%: both the sovereign and creditors (as a group) benefit from higher write-offs. Thus, any write-off lower than $21 \%$, including the standstill without a write-off, would be an inefficient debt relief from the perspective of the sovereign's welfare and the creditor's capital losses.

For write-offs between $21 \%$ and $47 \%$, there is a disagreement zone: while the sovereign prefers higher write-offs, lenders prefer lower write-offs, but compared with the standstill-only debt relief, lenders still have capital gains from write-offs. This disagreement zone includes all possible efficient outcomes of a debt relief with a one-year standstill. Only for write-offs higher than $47 \%$ there are creditors' losses in addition to those triggered by the standstill.

\subsection{Dynamics after the shock}

Figure 4 presents impulse response functions for key variables after the large shock (this is the only non-zero shock throughout the simulations presented in the figure). We consider five sets of simulations: (i) without debt relief, (ii) with a one-year standstill only, (iii) with the one-year standstill and the $20.9 \%$ write-off that minimizes creditor losses given the standstill, (iv) with the one-year standstill and the $47.1 \%$ write-off that maximizes the government's gains without additional creditor losses given the standstill, (v) without standstill and with the $47.3 \%$ write-off that produces the same capital losses as in (iv).

The figure shows that the standstill worsens the government's market access: on top of the spread increase because of the shock, the spread increases by an additional 800 basis points due to the standstill, and is higher than without debt relief throughout the projection period. This suggests that standstills' positive welfare effect in the short-term are of limited value. The higher spread reflects higher post-standstill default probabilities triggered by

\footnotetext{
${ }^{11}$ The sovereign and creditors' gains from write-offs would be more pronounced in a model in which the decline of sovereign risk implied by write-offs has a positive effect on aggregate income (Arellano et al., 2020b).
} 

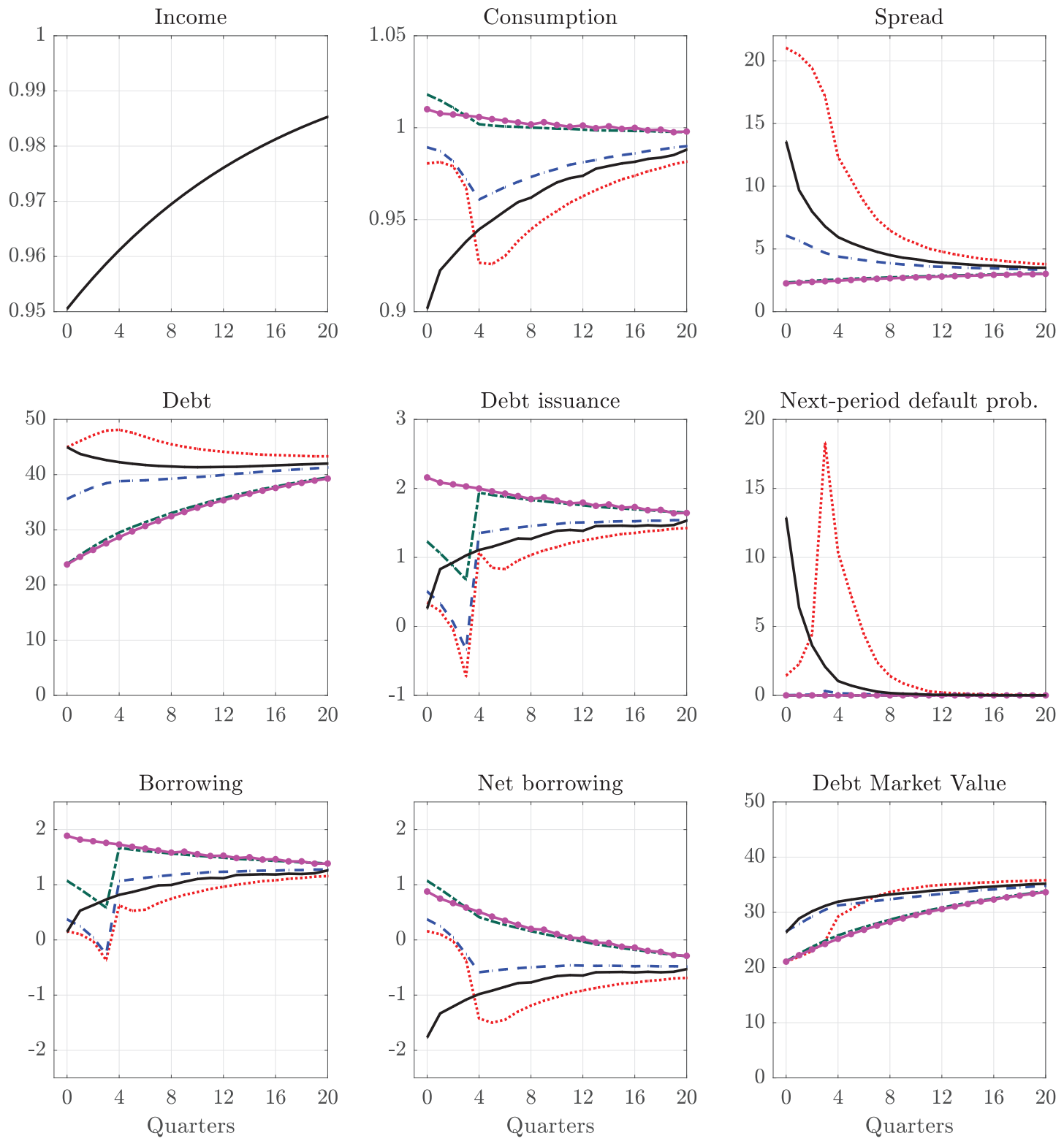

1 yr. DS \& $\theta=0 \% \quad---.1$ yr. DS \& $\theta=20.9 \%$

1 yr. DS \& $\theta=47.08 \%$

No DS \& $\theta=47.25 \%$

No Debt Relief

Figure 4: Impulse response functions for the baseline large shock. The size of the write-off is denoted by $\theta$. Consumption, the spread, debt, issuances, and borrowing are presented as percentage points. Consumption, debt issuances, and borrowing are divided by mean annual income. The spread and the bond price corresponds to the end-of-period equilibrium debt level. Beginning-of-period debt is divided by annualized income.

the standstill, despite lower default probabilities during the standstill, and accounts for the significant capital loss triggered by the standstill. Higher debt levels explain higher default probabilities. While issuances are lower with the standstill, debt levels are higher because of the debt that is automatically rolled over during the standstill. ${ }^{12}$

\footnotetext{
${ }^{12}$ The expectation of poor borrowing conditions even leads the government to buy back debt (negative debt issuances) before the standstill is over. It should be noticed that while a debt buyback after the shock may seem counterfactual, it is not an important feature of our exercise. Without the buyback (for example, if we allow the government to save by accumulating assets, or we assume
} 
Relatedly, while borrowing is lower during the standstill, net borrowing (net of debt payments) is higher.

During the standstill, all debt relief alternatives significantly mitigate the drop in consumption triggered by the shock. However, the standstill reduces consumption by itself in every period after the first year. This is the case because of poor borrowing conditions and larger net debt payments (more negative net borrowing) after the standstill.

In contrast, when the standstill is combined with the $20.9 \%$ write-off, consumption is even higher during the standstill and is significantly higher than without a debt write-off throughout the projection period. At the same time, spreads are significantly lower, and the debt market value is close to the one without debt relief. This is the case because the write-off lowers future debt obligations, thereby expanding the sovereign's borrowing opportunities.

Figure 4 also illustrates how including a standstill in the debt relief package does not always generate significant inefficiencies. A one-year standstill with a $47.1 \%$ write-off and a $47.3 \%$ write-off without a standstill generate almost identical paths for the debt level and the spread (and thus for the debt market value). These two debt relief packages also generate similar paths for consumption, and they result in almost identical welfare gains for the sovereign (Figure 3).

\subsection{Robustness}

To illustrate the robustness of our findings, we consider two other sets of shocks and a different initial debt level. We show that write-offs tend to dominate standstills in all cases, but when the income shock is accompanied by a sudden stop shock that eliminates access to debt markets, a slight role for standstills may appear. Appendix A shows that our results are also robust to the introduction of an empirically plausible recovery rate for defaulted debt.

First, one could argue that our baseline shocks are relatively small and more persistent than the COVID-19 shock (recall that the income autocorrelation coefficient is 0.94 ). This could be important for evaluating standstills that attempt to deal with COVID-19 with temporary debt relief. To address these concerns, we also study a set of "temporary" shocks such that mean income declines by $\chi$ for four quarters and then recovers by $\chi / 4$ in the next four quarters (returning to its pre-shock value in two years). The criteria for finding the size of our three baseline shocks (spread increases of 250 and 1000 basis points, and default) implies $\chi=5.7 \%, \chi=8.9 \%$, and $\chi=9.5 \%$. The top row of Figure 5 shows that for these more temporary shocks we find similar results to those obtained for our baseline shocks.

Second, our benchmark model assumes away shocks to external capital markets. This could bias our results in favor of write-offs, which imply an immediate expansion of the government's borrowing opportunities. Here,

the government needs to face extraordinary expenditures because of the shock), our results would be even stronger: the larger debt increase because of the standstill would lead to an even larger decline of the debt market value. Buybacks are rarely observed in default models because the government does not benefit from the increase in bond prices implied by a buyback (Aguiar et al., 2019; Bulow and Rogoff, 1988, 1991). 
(a) Temp. shock with $\chi=5.7 \%$

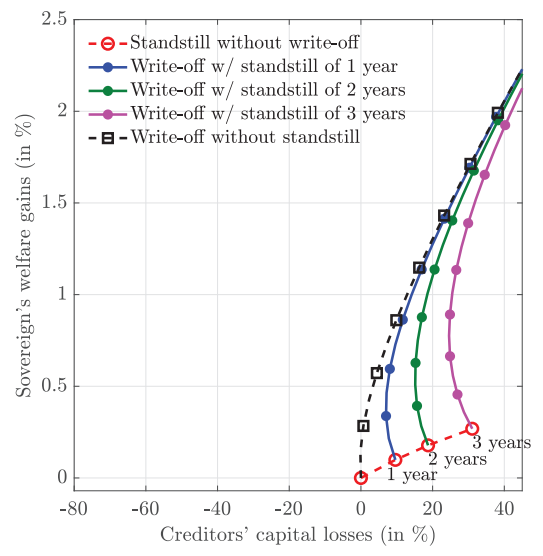

(d) $\Delta y_{t}=-3.2 \%$ and sudden stop

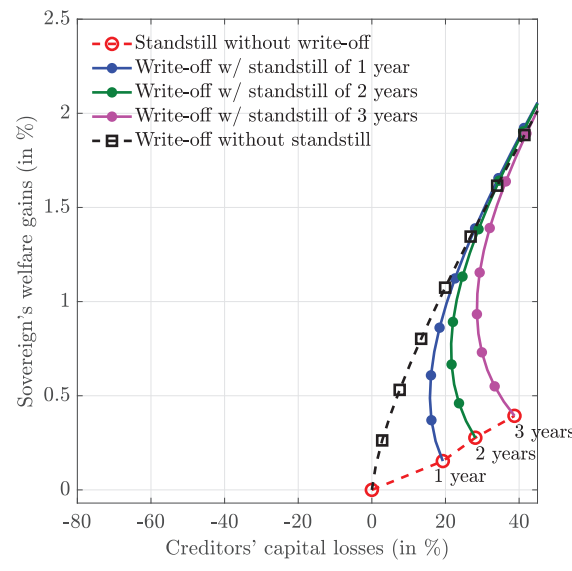

(g) $\Delta y_{t}=-3.2 \%$ and debt $=34 \%$

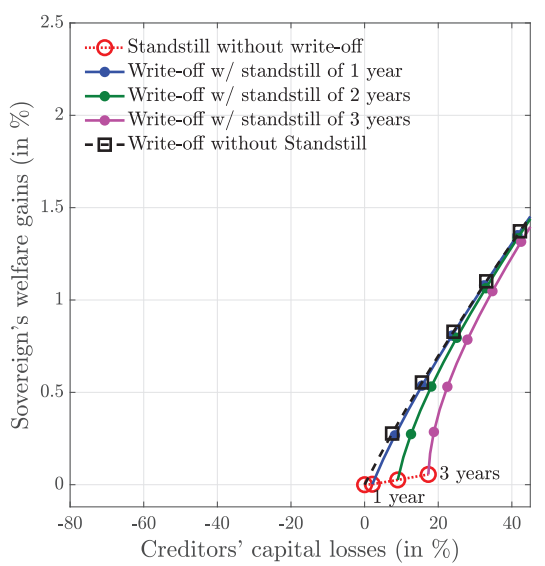

(b) Temp. shock with $\chi=8.9 \%$

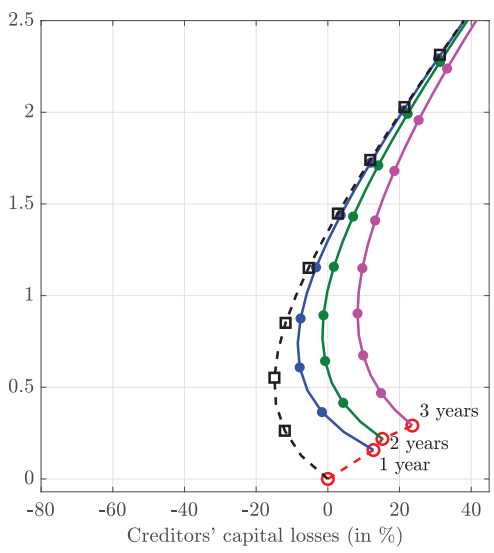

(e) $\Delta y_{t}=-5.4 \%$ and sudden stop

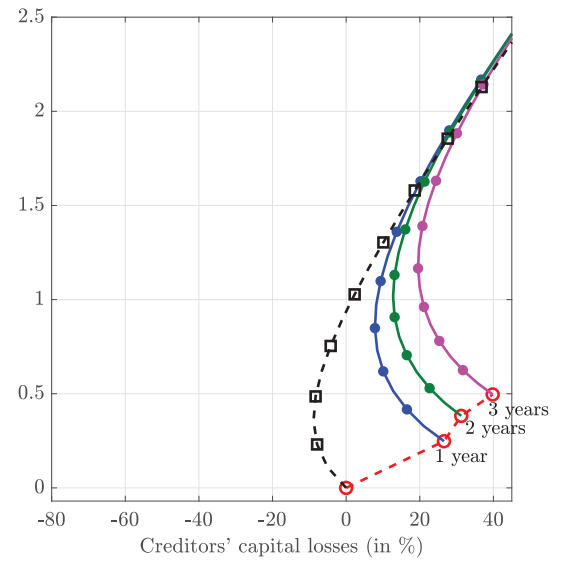

(h) $\Delta y_{t}=-5.4 \%$ and debt $=34 \%$

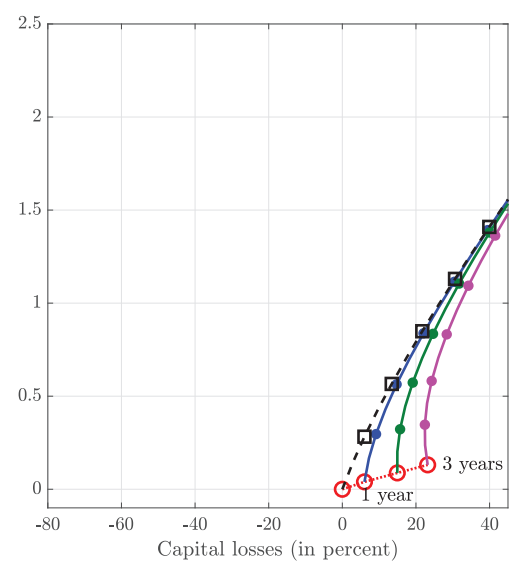

(c) Temp. shock with $\chi=9.5 \%$

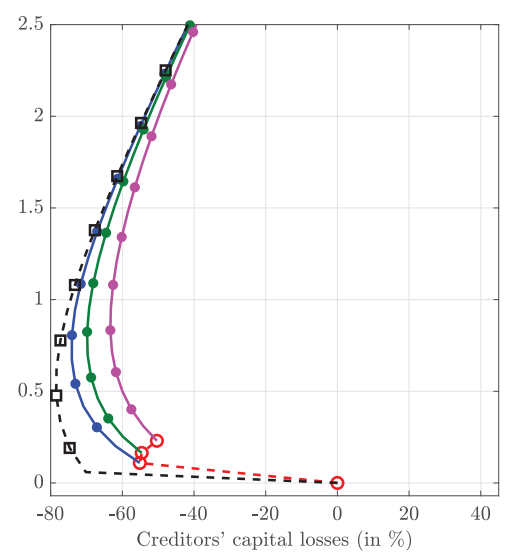

(f) $\Delta y_{t}=-6.8 \%$ and sudden stop

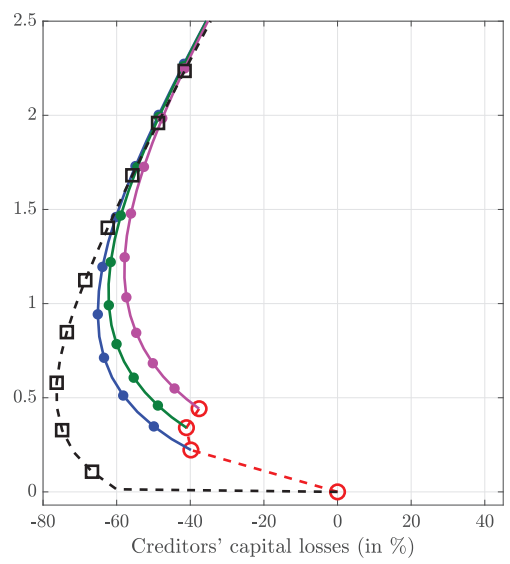

(i) $\Delta y_{t}=-6.8 \%$ and debt $=34 \%$

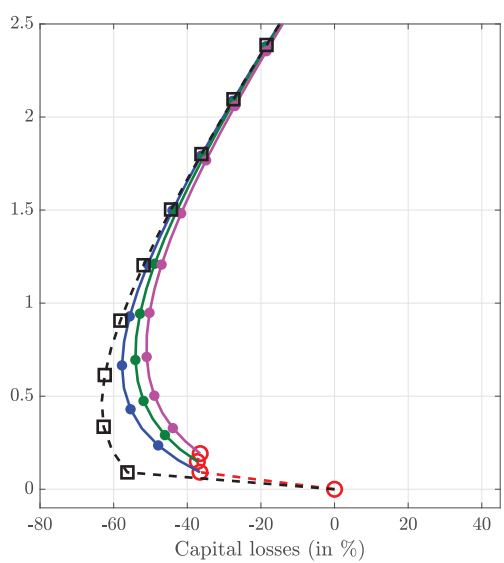

Figure 5: Sovereign's welfare gains and creditors' capital losses from implementing standstills and debt write-offs. The top row considers a temporary income shock that lasts for two years with an income decline of $\chi$ percent in the first year. The second row considers the baseline shocks with a sudden stop lasting one year. The last row considers the baseline shocks and an initial debt of $34 \%$ of mean GDP. 
in contrast, we assume the income shock is accompanied by a complete loss of access to debt markets (a market freeze). We add to the baseline shocks defined above a constraint that does not allow the government to borrow during the first four periods after the shock hits. ${ }^{13}$ This constraint has been used in the literature to model sudden stops (Sanchez et al., 2018), and could allow for a temporary payment suspension implemented through a standstill to be more beneficial than a write-off. The second row of Figure 5 shows that write-offs still tend to dominate standstills in this scenario, but implementing a standstill with write-offs higher than 35 percent can slightly increase welfare.

Third, we evaluate both policies starting from a debt ratio of 34 percent of mean income, for which the income shocks do not generate a debt overhang problem. This low-debt scenario allows us to illustrate how write-offs dominate standstills even without debt overhang. The third row of Figure 5 shows that with lower debt, capital losses and welfare gains are lower than when evaluated at the mean debt ratio (44 percent of income). With lower initial debt, capital losses from a standstill are lower because the increase in indebtedness triggered by the standstill increases less the default probability. The sovereign benefits less from the standstill because suspended debt payments are lower, and benefits less from write-offs because forgiven debt is lower and the default probability is less sensitive to the debt level.

\section{Conclusions}

The findings in this paper cast doubts on the emphasis on sovereign debt standstills without write-offs as the best alternative for providing debt relief to countries affected by adverse shocks, such as those associated with the COVID-19 outbreak. Standstills tend to increase debt and default risk after the payment suspension, thus leading sovereigns to endure higher deadweight costs of defaulting. Write-offs provide debt relief at the same time that they reduce default risk. By lowering the associated deadweight costs of defaulting, write-offs create a surplus to be shared between the sovereign and creditors. The benefits of write-offs are even higher when standstills produce a sovereign debt overhang. Adding write-offs to standstills can improve the government's welfare while lowering creditors' losses. To the extent that the emphasis on standstills without write-offs is the result of the regulatory cost of reductions in the nominal value of debt holdings (Dvorkin et al., 2020) or the emphasis on payment suspensions in the doctrine of necessity (Bolton et al., 2020), our results underscore that these legal frameworks could create significant inefficiencies in debt relief outcomes.

\footnotetext{
${ }^{13}$ Formally, we assume the following restriction on debt issuance during the market freeze:$$
\text { Debt issuance }= \begin{cases}b^{\prime}-(1-\delta) b \leq 0 & \text { without standstill } \\ b^{\prime}-(1-\delta)\left(1+r^{D S}\right) b \leq 0 & \text { with standstill. }\end{cases}
$$ 


\section{References}

Aguiar, Mark and Gita Gopinath, "Defaultable debt, interest rates and the current account," Journal of International Economics, 2006, 69, 64-83.

_ and _ , "Emerging markets business cycles: the cycle is the trend," Journal of Political Economy, 2007, 115 (1), 69-102.

_ , Manuel Amador, Hugo Hopenhayn, and Iván Werning, "Take the Short Route: Equilibrium Default and Debt Maturity," Econometrica, 2019, 87 (2), 423-462.

Arellano, Cristina, "Default Risk and Income Fluctuations in Emerging Economies," American Economic Review, 2008, 98(3), 690-712.

- and Ananth Ramanarayanan, "Default and the Maturity Structure in Sovereign Bonds," Journal of Political Economy, 2012, 120 (2), 187-232.

_ , Gabriel Mihalache, and Yan Bai, "Deadly Debt Crises: COVID-19 in Emerging Markets," 2020. Working Paper.

_, Xavier Mateos-Planas, and José-Víctor Ríos-Rull, "Partial Default," 2022. Manuscript.

_ , Yan Bai, and Luigi Bocola, "Sovereign Default Risk and Firm Heterogeneity," 2020. Manuscript.

Athreya, Kartik, Xuan S. Tam, and Eric R. Young, "Does Rising Income Risk Lead to Better Risk Sharing?," 2007. Manuscript, University of Virginia.

Barkbu, Bergljot, Barry Eichengreen, and Ashoka Mody, "Financial crises and the multilateral response: What the historical record shows," Journal of International Economics, 2012, 88, 422-435.

Bi, Huixin and Nora Traum, "Sovereign Risk and Fiscal Information: A Look at the U.S. State Default of the 1840s," 2020. Working Paper.

Bolton, Patrick, Lee Buchheit, Pierre-Olivier Gourinchas, Mitu Gulati, Chang-Tai Hsieh, Ugo Panizza, and Beatrice Weder di Mauro, "Born Out of Necessity: A Debt Standstill for COVID-19," CEPR Policy Insights, 2020, 103, 1-11.

Brooke, Martin, Rhys Mendes, Alex Pienkowski, and Eric Santor, "Sovereign Default and StateContingent Debt," 2011. Joint study of the Bank of Canada and the Bank of England.

Buiter, Willem H. and Anne C. Sibert, "UDROP: A Contribution to the New International Financial Architecture," International Finance, 1999, 2, 227-247. 
Bulow, Jeremy and Kenneth Rogoff, "The Buyback Boondoggle," Brookings Papers on Economic Activity, 1988, 1988 (2), 675-704.

_ and _, "Sovereign Debt Repurchases: No Cure for Overhang," Quarterly Journal of Economics, 1991, 106 (4), 1219-35.

Chatterjee, S. and B. Eyigungor, "Maturity, Indebtedness and Default Risk," American Economic Review, 2012, 102(6), 2674-2699.

_ and _, "A Seniority Arrangement for Sovereign Debt," American Economic Review, 2015, 105(12), 37403765 .

Chatterjee, Satyajit, Dean Corbae, M. Nakajima, and José-Víctor Ríos-Rull, "A Quantitative Theory of Unsecured Consumer Credit with Risk of Default," Econometrica, 2007, 75, 1525-1589.

Consiglio, Andrea and Stavros A. Zenios, "The case for contingent convertible debt for sovereigns," 2015. The Wharton Financial Institutions Center, Working Paper 15-13.

Cruces, Juan J. and Christoph Trebesch, "Sovereign Defaults: The Price of Haircuts," American Economic Journal: Macroeconomics, 2013, 5(3), 85-117.

Cruces, Juan José, Marcos Buscaglia, and Joaquín Alonso, "The Term Structure of Country Risk and Valuation in Emerging Markets," 2002. manuscript, Universidad Nacional de La Plata.

David, Antonio C., Jaime Guajardo, and Juan F. Yépez, "The Rewards of Fiscal Consolidation: Sovereign Spreads and Confidence Effects," IMF Working Papers /19/141, 2019.

Dias, Daniel A. and Christine Richmond, "Duration of Capital Market Exclusion: An Empirical Investigation," 2007. Working Paper, UCLA.

Dvorkin, Maximiliano, Juan M. Sanchez, Horacio Sapriza, and Emircan Yurdagul, "Sovereign Debt Restructurings," AEJ: Macroeconomics, 2020, forthcoming.

Eaton, Jonathan and Mark Gersovitz, "Debt with potential repudiation: theoretical and empirical analysis," Review of Economic Studies, 1981, 48, 289-309.

Froot, Kenneth A., "Buybacks, Exit Bonds, and the Optimality of Debt and Liquidity Relief," International Economic Review, 1989, 30 (1), 49-70.

Gu, Grace Weishi and Zachary R. Stangebye, "Costly Information and Heteroskedasticity in Sovereign Risk Spreads," 2018. Working Paper.

Hatchondo, Juan Carlos and Leonardo Martinez, "Long-duration bonds and sovereign defaults," Journal of International Economics, 2009, 79, 117-125. 
_ and _, Calibrating the Cost of Defaulting in Models of Sovereign Defaults, Cambridge: Cambridge University Press, 2017.

_ , _, , and Juan M. Sanchez, "Mortgage defaults," Journal of Monetary Economics, 2015, 76, 173-190.

_ , _, and César Sosa-Padilla, "Voluntary Sovereign Debt Exchanges," Journal of Monetary Economics, $2014,61,32-50$.

_ , _ , and _ , "Debt dilution and sovereign default risk," Journal of Political Economy, 2016, 124(5), 1383-1422.

_, _, and Francisco Roch, "Constrained Efficient Borrowing with Sovereign Default Risk," 2020. Manuscript.

_ , _, and _, "Fiscal rules and the sovereign default premium," 2020. Manuscript.

_ , _, and Horacio Sapriza, "Quantitative properties of sovereign default models: solution methods matter," Review of Economic Dynamics, 2010, 13 (4), 919-933.

_ , _, Yasin Kürşat Önder, and Francisco Roch, "Sovereign cocos," 2020. Manuscript.

IMF, "State-Contingent Debt Instruments for Sovereigns," 2017. IMF Policy Paper. International Monetary Fund.

_ , "State-Contingent Debt Instruments for Sovereigns-Annexes," 2017. IMF Policy Paper. International Monetary Fund.

_ , "A Cautious Reopening," 2020. Sub-Saharan Africa Regional Economic Outlook June 2020 Update. International Monetary Fund.

Jaramillo, Laura and Catalina Michelle Tejada, "Sovereign Credit Ratings and Spreads in Emerging Markets; Does Investment Grade Matter?," IMF Working Papers 11/44, 2011.

Krugman, Paul, "Financing vs. forgiving a debt overhang," Journal of Development Economics, 1988, 29 (3), 253-268.

_., "Market-based debt-reduction schemes," 1988. NBER Working Paper 2587.

Li, Wenli and Pierre-Daniel Sarte, "U.S. consumer bankruptcy choice: The importance of general equilibrium effects," Journal of Monetary Economics, 2006, 53, 613-631.

Livshits, I., J. MacGee, and M. Tertilt, "Consumer Bankruptcy: A Fresh Start,", American Economic Review, 2008, 97, 402-418.

Mallucci, E., "Natural disasters, climate change, and sovereign risk," 2020. FRB International Finance Discussion Paper 1291. 
Mihalache, Gabriel, "Sovereign default resolution through maturity extension," Journal of International Economics, 2020, 125C.

Neumeyer, Pablo. and Fabrizio Perri, "Business cycles in emerging economies: the role of interest rates," Journal of Monetary Economics, 2005, 52, 345-380.

Phan, Toan and Felipe Schwartzman, "Disasters and Defaults," 2020. Manuscript.

Sachs, Jeffrey, The Debt Overhang of Developing Countries, Oxford: Basil Blackwell, 1989.

Sanchez, Juan M., Horacio Sapriza, and Emircan Yurdagul, "Sovereign Default and Maturity Choice," Journal of Monetary Economics, 2018, 95, 72-85.

Sunder-Plassmann, Laura, "Writing off sovereign debt: Default and recovery rates over the cycle," Journal of International Money and Finance, 2018, 81, 221-241.

Uribe, Martín and Vivian Yue, "Country spreads and emerging countries: Who drives whom?," Journal of International Economics, 2006, 69, 6-36.

Weber, Axel A., Jens Ulbrich, and Karsten Wendorff, "Safeguarding financial market stability, strengthening investor responsibility, protecting taxpayers A proposal to reinforce the European Stability Mechanism through supplementary bond issuance terms," 2011. Research Paper, Deutsche Bundesbank.

Wright, Mark L. J., "Restructuring Sovereign Debts with Private Sector Creditors: Theory and Practice," 2011. In Sovereign Debt and the Financial Crisis: Will This Time Be Different?, eds. Carlos A. Primo Braga and Gallina A. Vincelette. 2011, World Bank: Washington, D.C., Pages 295-315. 


\section{Appendix}

\section{A A positive recovery rate}

In this appendix, we show that our main results are robust to assuming a positive recovery rate on defaulted debt. In particular, we assume that after a default event, debt is not vanished but instead is equal to a fraction of the mean debt in the simulations. This specification implies that the recovery rate decreases with debt, as documented by, for example, Sunder-Plassmann (2018).

Formally, the recursive formulation of the model with positive recovery is:

$$
V(b, y)=\max _{d \epsilon\{0,1\}}\left\{d V_{1}(b, y)+(1-d) V_{0}(b, y)\right\}
$$

where the value of default is:

$$
V_{1}(b, y)=u(y-\phi(y))+\beta \int\left[\psi V\left(b_{D}, y^{\prime}\right)+(1-\psi) V_{1}\left(b_{D}, y^{\prime}\right)\right] F\left(d y^{\prime} \mid y\right),
$$

and $b_{D}=\min \{\alpha, b\}$ is the 'recovered' debt level. The value of repayment is:

subject to

$$
V_{0}(b, y)=\max _{b^{\prime} \geq 0}\left\{u\left(y-b+q\left(b^{\prime}, y\right)\left[b^{\prime}-(1-\delta) b\right]\right)+\beta \int V\left(b^{\prime}, y^{\prime}\right) F\left(d y^{\prime} \mid y\right)\right\} .
$$

$$
b^{\prime}>(1-\delta) b \text { only if } q\left(b^{\prime}, y\right)>\underline{q},
$$

where the constraint precludes the government from issuing bonds below the price $\underline{q} .{ }^{14}$ The bond price is given by the following functional equation:

$$
\begin{aligned}
q\left(b^{\prime}, y\right)= & \frac{1}{1+r} \int\left[1-\hat{d}\left(b^{\prime}, y^{\prime}\right)\right]\left[1+(1-\delta) q\left(\hat{b}\left(b^{\prime}, y^{\prime}\right), y^{\prime}\right)\right] F\left(d y^{\prime} \mid y\right) \\
& +\frac{1}{1+r} \int \hat{d}\left(b^{\prime}, y^{\prime}\right) q^{D}\left(b^{\prime}, y^{\prime}\right) F\left(d y^{\prime} \mid y\right)
\end{aligned}
$$

where

$$
\begin{aligned}
q^{D}(b, y)= & \frac{1-\psi}{1+r} \int \frac{b_{D}}{b} q^{D}\left(b_{D}, y^{\prime}\right) F\left(d y^{\prime} \mid y\right) \\
& +\frac{\psi}{1+r} \int\left[1-\hat{d}\left(b_{D}, y^{\prime}\right)\right] \frac{b_{D}}{b}\left[1+(1-\delta) q\left(\hat{b}\left(b_{D}, y^{\prime}\right), y^{\prime}\right)\right] F\left(d y^{\prime} \mid y\right) \\
& +\frac{\psi}{1+r} \int \hat{d}\left(b_{D}, y^{\prime}\right) \frac{b_{D}}{b} q^{D}\left(b_{D}, y^{\prime}\right) F\left(d y^{\prime} \mid y\right)
\end{aligned}
$$

denotes the price of a bond in default.

\footnotetext{
${ }^{14}$ With a positive recovery rate and long-term debt, the period before defaulting, the government may want to issue an infinite amount of debt that fully dilutes the value of previous debt claims, financing a consumption boom. As in Hatchondo et al. (2016), in order to avoid this problem, we assume that the government cannot sell bonds with a price lower than $q$. We choose a value of $q$ that (i) eliminates consumption booms before defaults, (ii) is never binding in the simulations, and (iii) allows for debt issuances at the sovereign spread levels observed in the data.
} 


\section{Calibration and model fit}

We need to assign values to two new parameters: $\alpha$ and $\underline{q}$. We assume that $\underline{q}=\frac{0.5}{r+\delta}$, which is never binding in the simulations. This value for $\underline{q}$ implies that the government can never issue debt at a price lower than $50 \%$ of the risk-free price. We set $\alpha=0.62$, which amounts to $35 \%$ of the mean debt in the simulations and is thus consistent with the average haircut of $65 \%$ reported by Cruces and Trebesch (2013) for debt restructurings with reductions in face value (as the ones we model).

We recalibrate the parameters of the income cost of defaulting, $\lambda_{0}$ and $\lambda_{1}$, to match the same moments we targeted in the main body of the paper: an average debt-to-GDP ratio of 44 percent and a mean spread of 3.4 percent. All other parameter values remain unchanged. Table A.1 reports all the parameter values.

Table A.1: Parameter values.

\begin{tabular}{lccc}
\hline \hline Risk aversion & $\gamma$ & 2 & Standard \\
Risk-free rate & $r$ & $1 \%$ & Standard \\
Discount factor & $\beta$ & 0.9745 & Standard \\
Probability default ends & $\psi$ & 0.083 & $\mathbb{E}$ (exclusion) $=3$ years \\
Debt duration & $\delta$ & 0.033 & Debt duration $=5$ years \\
Income autocorrelation coefficient & $\rho$ & 0.94 & Mexico GDP \\
Standard deviation of innovations & $\sigma_{\epsilon}$ & $1.5 \%$ & Mexico GDP \\
Mean log income & $\mu$ & $(-1 / 2) \sigma_{\epsilon}^{2}$ & Mexico GDP \\
Price floor & $\underline{q}$ & $0.5 /(\delta+r)$ & never binding \\
Recovered debt & $\alpha$ & 0.62 & $35 \%$ recovery rate \\
\hline \multicolumn{2}{c}{ Calibrated to match targets } \\
Income cost of defaulting & $\lambda_{0}$ & 0.15 & Average debt $=44 \%$ \\
Income cost of defaulting & $\lambda_{1}$ & 1.33 & Average spread $=3.4 \%$ \\
\hline \hline
\end{tabular}

Table A.2 shows that the model simulations (with positive recovery) match the targeted levels of debt and spread. The model with recovery also does a good job in mimicking other non-targeted moments.

Table A.2: Business Cycle Statistics

\begin{tabular}{|c|c|c|}
\hline \multicolumn{3}{|c|}{ Targeted moments } \\
\hline Mean Debt-to-GDP & 44 & 44 \\
\hline Mean $r_{s}$ & 3.4 & 3.4 \\
\hline \multicolumn{3}{|c|}{ Non-Targeted moments } \\
\hline$\sigma(c) / \sigma(y)$ & 1.3 & 1.2 \\
\hline$\sigma(t b)$ & 0.6 & 1.4 \\
\hline$\sigma\left(r_{s}\right)$ & 1.3 & 1.5 \\
\hline$\rho(t b, y)$ & -0.8 & -0.7 \\
\hline$\rho(c, y)$ & 0.99 & 0.93 \\
\hline$\rho\left(r_{s}, y\right)$ & -0.8 & -0.5 \\
\hline$\rho\left(r_{s}, t b\right)$ & 0.7 & 0.6 \\
\hline
\end{tabular}




\section{Robustness of the main results}

We next show that the main insights of our paper are robust to assuming a positive recovery rate for defaulted debt. We focus on the more realistic "temporary" shocks defined in the paper (drops of mean income). The "small" shock increases spread by 250 bps (3.6\% decline of mean income) and the "large" shock by 1000 bps (7.1\% decline). The "default" shock is the smallest decline that triggers a default without standstills (and thus is such that the government repays with a standstill; $7.6 \%$ ).

Figure A.1 presents the effects of different forms of debt relief when we assume a positive recovery rate. As it was the case in the no-recovery model, standstills produce welfare gains for the sovereign but, except when they avoid a default (right panel), they produce capital losses for lenders. ${ }^{15}$ In general, capital losses triggered by a standstill can be mitigated with haircuts that also increase sovereign welfare. ${ }^{16}$ Using only haircuts continues to be the best form of debt relief, but losses from combining haircuts with a standstill are less significant for larger haircuts.
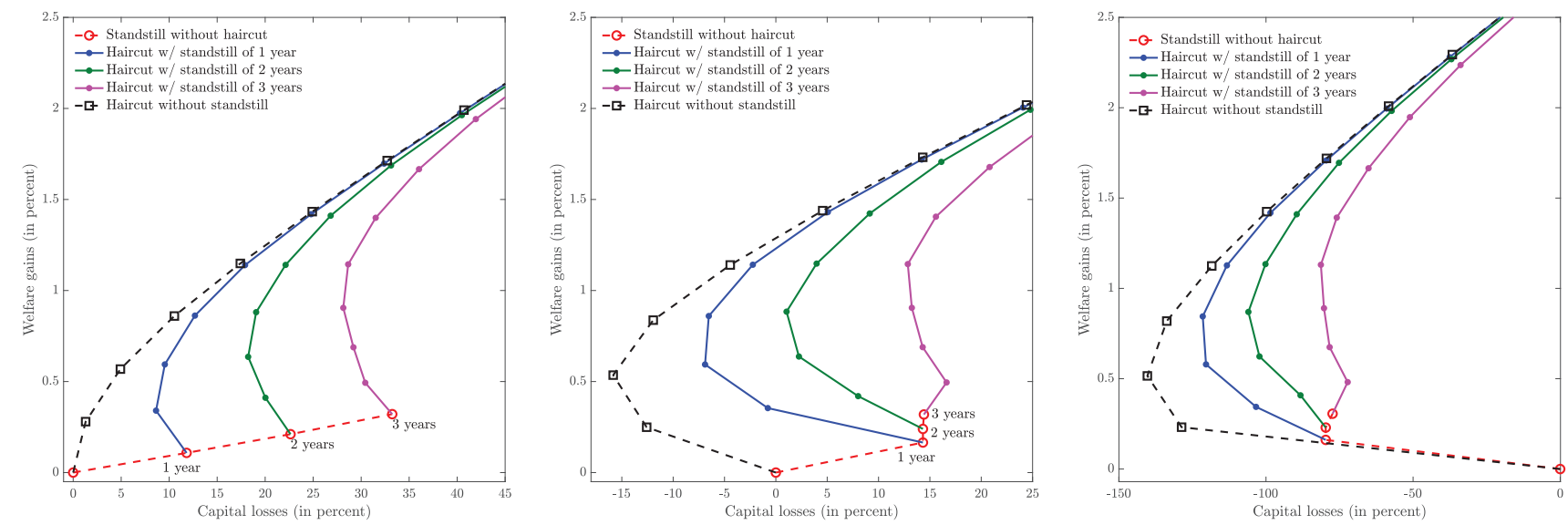

Figure A.1: Sovereign's welfare gain and creditors' capital losses in the economy with positive recovery. This figure is the counterpart to Figure 1's middle row in the main body of the paper.

\footnotetext{
${ }^{15}$ The debt market value is

$$
M V(b, y)=b[1-\hat{d}(b, y)][1+(1-\delta) q(\hat{b}(b, y), y)]+b_{D} \hat{d}(b, y) q^{D}\left(b_{D}, y\right)
$$

without standstills and

$$
\left.M V^{D S_{j}}(b, y)=b\left[1-\hat{d}^{D S_{j}}(b, y)\right]\left(1+r^{D S}\right) q^{D S_{j}}\left(\hat{b}^{D S_{j}}(b, y), y\right)\right]+b_{D} \hat{d}^{D S_{j}}(b, y) q^{D}\left(b_{D}, y\right)
$$

with standstills.

${ }^{16}$ In contrast with the exercises in the paper, Figure A.1 shows that for the larger shocks, haircuts do not mitigate significantly the capital losses triggered by the the 3 years standstill. The expected increase in indebtedness during the 3 years standstill would undo the positive effect of haircuts on the default probability, undermining the possibility of Pareto gains from haircuts. Note however, that haircuts can still increase significantly the sovereign's welfare gains, and that the 3 years standstill is strongly Pareto dominated by other forms of debt relief.
} 


\section{B A two-period model}

We next present a stylized two-period model that illustrates why write-offs may be preferred over standstills. We show that by lowering future debt, and thus, by lowering the future default probability, write-offs reduce the deadweight cost of defaulting relative to a standstill. We also show that write-offs can dominate a standstill in a setup with a sudden stop in period 1. Intuitively, standstills tend to generate a short-term gain at the expense of a long-term loss due to additional debt accumulation. Therefore, the key property for preferring a write-off over a standstill is that the sovereign is not too impatient.

Environment. There are two periods, 1 and 2. Both the borrower and lenders are risk neutral. Lenders operate in a competitive environment and have a discount factor of 1 . The borrower's discount factor $\beta \in(0,1)$. The borrower's initial debt is given by $b>0$ legacy bonds. Each legacy bond pays a coupon of $\delta$ units in period 1 and a principal of 1 unit in period 2. The borrower can default in period 2 (we abstract from default incentives in period 1). There is a stochastic resource/utility cost of defaulting $\phi$ with support $[0, \bar{b}]$. The pdf for $\phi$ is denoted by $f$ and its cdf by $F$. The density $f$ is continuous, and $f>0$ for all $\phi \in[0, \bar{b}]$. There is no income.

Value under repayment. The government defaults in period 2 if $b>\phi$. Thus, the borrower repays $b$ with probability $1-F(b)$ and its expected utility in default states is $-\int_{0}^{b} \phi f(\phi) d \phi$. This implies that in period 1 , a borrower that starts with $b$ bonds expects a continuation value of

$$
V(b)=\underset{b^{\prime} \in[0, \bar{b}]}{\operatorname{Max}}\{\underbrace{-\delta b+q\left(b^{\prime}\right)\left(b^{\prime}-b\right)}_{c}-\beta\left[1-F\left(b^{\prime}\right)\right] b^{\prime}-\beta \int_{0}^{b^{\prime}} \phi f(\phi) d \phi\} .
$$

Risk-neutrality and the assumption $\beta<1$ imply the government has no incentive to save. Given that we are going to focus on cases with $b>0$, the constraint $b^{\prime} \geq 0$ is not binding. The objective function is flat in $b^{\prime}$ for $b^{\prime} \geq \bar{b}$, so the constraint $b^{\prime} \leq \bar{b}$ is not restrictive. We are going to use $\hat{b}$ to denote the optimal borrowing rule of the problem above.

Bond price. Competition between lenders ensure that the equilibrium bond price schedule satisfies

$$
q\left(b^{\prime}\right)=1-F\left(b^{\prime}\right)
$$

Standstill. A debt standstill consists on postponing the payment of the $\delta b$ coupons maturing in period 1 . The value of repaying with a standstill satisfies

$$
V^{D S}(b)=\underset{b^{\prime} \in[0, \bar{b}]}{\operatorname{Max}}\left\{q\left(b^{\prime}\right)\left(b^{\prime}-b(1+\delta)\right)-\beta\left[1-F\left(b^{\prime}\right)\right] b^{\prime}-\beta \int_{0}^{b^{\prime}} \phi f(\phi) d \phi\right\} .
$$

We are going to use $\hat{b}^{D S}$ to denote the optimal borrowing rule with a standstill. 
The following lemma establishes useful properties for the propositions that follow. It shows the continuity of functions $V$ and $V^{D S}$, and that the optimal borrowing is interior and continuous. For the latter, we need the following assumption.

Assumption 1 The density $f$ is such that

$$
\left[1-F\left(b^{\prime}\right)\right]\left(b^{\prime}-b\right)-\beta\left[1-F\left(b^{\prime}\right)\right] b^{\prime}-\beta \int_{0}^{b^{\prime}} \phi f(\phi) d \phi
$$

is strictly concave for all $b>0, \beta \in(0,1) .{ }^{17}$

Lemma 2 Given assumption 1, the functions $V$ and $V^{D S}$ are continuous in $b$ and $\beta$. The borrowing rule $\hat{b}(b) \in(0, \bar{b})$ for $b \in[0, \bar{b})$ and is continuous. The borrowing rule $\hat{b}^{D S}(b) \in(0, \bar{b})$ for $b \in[0, \bar{b} /(1+\delta))$.

Proof. The continuity of $\left\{V, V^{D S}, \hat{b}\right\}$ follow from the continuity of the objective functions in problems (A.1)(A.2), the compactness and continuity of the choice set $[0 \bar{b}]$, the strict concavity of the objective function in equation (A.1), and the theory of the maximum.

The first order derivative of the objective function in equation (A.1)

$$
\left[1-F\left(b^{\prime}\right)\right](1-\beta)-f\left(b^{\prime}\right)\left(b^{\prime}-b\right)>0 \quad \forall b^{\prime} \leq 0 \text { and } b \geq 0,
$$

implying that $\hat{b}(b)>0$.

Given that $f(\bar{b})>0$, the first order derivative

$$
\left[1-F\left(b^{\prime}\right)\right](1-\beta)-f\left(b^{\prime}\right)\left(b^{\prime}-b\right)<0 \quad \text { evaluated at } b^{\prime}=\bar{b} \text { and for } b<\bar{b},
$$

implying that $\hat{b}(b)<\bar{b}$.

The proof for $\hat{b}^{D S}(b) \in(0, \bar{b})$ is analogous.

In what follows, we restrict attention to initial debt levels $b \in[0, \bar{b} /(1+\delta))$, which ensures the first order conditions hold with equality. The next proposition shows that both, standstills and write-offs are welfare enhancing for the government.

Proposition $3 V^{D S}(b)>V(b)$ and $V(b(1-\theta))>V(b)$ for all $b \in[0, \bar{b} /(1+\delta))$ and write-off magnitudes $\theta \in(0,1)$.

\section{Proof.}

$$
\begin{aligned}
V(b) & =-\delta b-q(\hat{b}(b)) b+q(\hat{b}(b)) \hat{b}(b)-\beta[1-F(\hat{b}(b))] \hat{b}(b)-\beta \int_{0}^{\hat{b}(b)} \phi f(\phi) d \phi \\
& <-\delta b q(\hat{b}(b))-q(\hat{b}(b)) b+q(\hat{b}(b)) \hat{b}(b)-\beta[1-F(\hat{b}(b))] \hat{b}(b)-\beta \int_{0}^{\hat{b}(b)} \phi f(\phi) d \phi \\
& \leq-q\left(\hat{b}^{D S}(b)\right) b(1+\delta)+q\left(\hat{b}^{D S}(b)\right) \hat{b}^{D S}(b)-\beta\left[1-F\left(\hat{b}^{D S}(b)\right)\right] \hat{b}^{D S}(b)-\beta \int_{0}^{\hat{b}^{D S}(b)} \phi f(\phi) d \phi \\
& =V^{D S}(b)
\end{aligned}
$$

\footnotetext{
${ }^{17} \mathrm{An}$ example of such probability distribution is the uniform one.
} 
where the second line follows from $\hat{b}(b)>0$ and, thus, $q(\hat{b}(b))<1$, and the third line follows from the definition of $\hat{b}^{D S}$.

The inequality $V(b(1-\theta))>V(b)$ is trivial.

Proposition 3 shows that both debt-relief policies do increase the sovereign's welfare. The question is if we can rank between the two debt relief policies. For that, we will need the following Lemma.

Lemma 4 The borrowing policy $\hat{b}(b)$ is strictly increasing and $\hat{b}^{D S}(b)>\hat{b}(b)$ for all $b \in[0, \bar{b} /(1+\delta))$ and write-off percentages $\theta \in(0,1)$.

Proof. Let $0 \leq b_{0}<b_{1}<\bar{b} /(1+\delta)$. In order to simplify notation, let $b_{i}^{\prime}=\hat{b}\left(b_{i}\right)$ for $i=0,1$.

First, the optimality of $b_{0}^{\prime}$ for $b=b_{0}$ implies

$$
\begin{aligned}
& -\left(\delta+1-F\left(b_{0}^{\prime}\right)\right) b_{0}+\left(1-F\left(b_{0}^{\prime}\right)\right)(1-\beta) b_{0}^{\prime}-\beta \int_{0}^{b_{0}^{\prime}} \phi f(\phi) d \phi- \\
& {\left[-\left(\delta+1-F\left(b^{\prime}\right)\right) b_{0}+\left(1-F\left(b^{\prime}\right)\right)(1-\beta) b^{\prime}-\beta \int_{0}^{b^{\prime}} \phi f(\phi) d \phi\right] \geq 0 \text { for all } b^{\prime} \leq b_{0}^{\prime},}
\end{aligned}
$$

which is equivalent to

$$
\left[F\left(b_{0}^{\prime}\right)-F\left(b^{\prime}\right)\right] b_{0}+(1-\beta)\left[\left(1-F\left(b_{0}^{\prime}\right)\right) b_{0}^{\prime}-\left(1-F\left(b^{\prime}\right)\right) b^{\prime}\right]-\beta \int_{b^{\prime}}^{b_{0}^{\prime}} \phi f(\phi) d \phi \geq 0 \text { for all } b^{\prime} \leq b_{0}^{\prime} .
$$

Equation A.3 and $F\left(b_{0}^{\prime}\right)-F\left(b^{\prime}\right) \geq 0$ imply

$$
\left[F\left(b_{0}^{\prime}\right)-F\left(b^{\prime}\right)\right] b_{1}+(1-\beta)\left[\left(1-F\left(b_{0}^{\prime}\right)\right) b_{0}^{\prime}-\left(1-F\left(b^{\prime}\right)\right) b^{\prime}\right]-\beta \int_{b^{\prime}}^{b_{0}^{\prime}} \phi f(\phi) d \phi \geq 0 \text { for all } b^{\prime} \leq b_{0}^{\prime} .
$$

Inequality A.4 implies that $b_{1}^{\prime} \geq b_{0}^{\prime}$.

The derivative of the objective function for initial debt $b=b_{1}$ at $b^{\prime}=b_{0}^{\prime}$

$$
\left[1-F\left(b_{0}^{\prime}\right)\right](1-\beta)-f\left(b_{0}^{\prime}\right)\left(b_{0}^{\prime}-b_{1}\right)>\underbrace{\left[1-F\left(b_{0}^{\prime}\right)\right](1-\beta)-f\left(b_{0}^{\prime}\right)\left(b_{0}^{\prime}-b_{0}\right)=0}_{\text {First order condition for } b^{\prime} \text { with initial debt } b=b_{0}},
$$

implying that the objective function is strictly increasing at $b^{\prime}=b_{0}$ when the government enters period 1 with $b=b_{1}$. Equations (A.4)-(A.5) imply $b_{1}^{\prime}>b_{0}^{\prime}$.

Regarding the second part of the lema, notice that debt payments in period 1 do not affect optimal borrowing. Thus,

$$
\begin{aligned}
\hat{b}^{D S}(b) & =\underset{b^{\prime}}{\operatorname{Argmax}}\left\{q\left(b^{\prime}\right)\left(b^{\prime}-b(1+\delta)\right)-\beta\left[1-F\left(b^{\prime}\right)\right] b^{\prime}-\beta \int_{0}^{b^{\prime}} \phi f(\phi) d \phi\right\} \\
& =\underset{b^{\prime}}{\operatorname{Argmax}}\left\{-\delta(1+\delta) b+q\left(b^{\prime}\right)\left(b^{\prime}-b(1+\delta)\right)-\beta\left[1-F\left(b^{\prime}\right)\right] b^{\prime}-\beta \int_{0}^{b^{\prime}} \phi f(\phi) d \phi\right\} \\
& =\hat{b}(b(1+\delta)) .
\end{aligned}
$$


From the first part of the lemma, we know $\hat{b}(b(1+\delta))>\hat{b}(b)$

Intuitively, Lemma 4 follows from the stronger incentives to dilute debt when the government enters a period with higher debt. The stronger incentives to issue debt with a standstill lead the government to issue debt at a lower price. This unequivocally lowers the market value of debt because i) a standstill swaps a sure coupon payment $\delta b$ in $t=1$ for an uncertain payment in $t=2$, and ii) the payment due at $t=2$ is subject to a higher default probability. This capital loss resembles ones shown in Figure 2.

The next proposition shows the main result of the paper through the lens of the stylized model. It shows why write-offs may dominate standstills. Formally, the proposition establishes that when the sovereign is sufficiently patient, we can always find a write-off that leaves lenders indifferent between the write-off and the standstill, while leaving the sovereign strictly better off than with the standstill.

Proposition 5 For any $b \in[0, \bar{b} /(1+\delta))$, there exists a cutoff $\underline{\beta}(b)$ and write-off $\theta^{*}$ such that:

$$
\begin{aligned}
& V\left(b\left(1-\theta^{*}\right)\right)>V^{D S}(b), \text { and } \\
& b\left(1-\theta^{*}\right)\left(\delta+q\left(\hat{b}\left(b\left(1-\theta^{*}\right)\right)\right)\right)=b q\left(\hat{b}^{D S}(b)\right)(1+\delta) \quad \text { for all } \beta \in(\underline{\beta}(b), 1) .
\end{aligned}
$$

\section{Proof.}

Since creditors experience a capital loss with a standstill, i.e.,

$$
b q\left(\hat{b}^{D S}(b)\right)(1+\delta)<b[\delta+q(\hat{b}(b))]
$$

and the market value is a continuous function, it is always possible to find a write-off $\theta^{*} \in(0,1)$ that replicates the capital loss generated by the standstill. Using $b_{\theta^{*}}^{\prime}=\hat{b}\left(b\left(1-\theta^{*}\right)\right)$ and $b_{D S}^{\prime}=\hat{b}^{D S}(b)$, the differential welfare effect for the sovereign

$$
\begin{aligned}
V\left(b\left(1-\theta^{*}\right)\right)-V^{D S}(b)= & -b\left(1-\theta^{*}\right)\left[\delta+q\left(b_{\theta^{*}}^{\prime}\right)\right]+q\left(b_{\theta^{*}}^{\prime}\right) b_{\theta^{*}}^{\prime}-\beta\left[1-F\left(b_{\theta^{*}}^{\prime}\right)\right] b_{\theta^{*}}^{\prime}-\beta \int_{0}^{b_{\theta^{*}}^{\prime}} \phi f(\phi) d \phi- \\
& {\left[-b q\left(b_{D S}^{\prime}\right)(1+\delta)+q\left(b_{D S}^{\prime}\right) b_{D S}^{\prime}-\beta\left[1-F\left(b_{D S}^{\prime}\right)\right] b_{D S}^{\prime}-\beta \int_{0 S}^{b_{D S}^{\prime}} \phi f(\phi) d \phi\right] } \\
= & \underbrace{\left(q\left(b_{\theta^{*}}^{\prime}\right) b_{\theta^{*}}^{\prime}-q\left(b_{D S}^{\prime}\right) b_{D S}^{\prime}\right)}_{c_{1}\left(b\left(1-\theta^{*}\right)\right)-c_{1}^{D S}(b)}(1-\beta)+\beta \times \underbrace{\int_{b_{\theta^{*}}^{\prime}}^{b_{D S}^{\prime}} \phi f(\phi) d \phi}_{E\left[c_{2}\left(b\left(1-\theta^{*}\right)\right)-c_{2}^{D S}(b)\right]>0}=g(\beta)
\end{aligned}
$$

At $\beta=1$, the government does not have an incentive to save nor borrow and, therefore, $\operatorname{chooses} b_{\theta^{*}}^{\prime}=b\left(1-\theta^{*}\right)$ and $b_{D S}^{\prime}=b(1+\delta)$. This implies $g(1)>0$, which jointly with continuity of $g$ (Lemma 2) means there exists a cutoff $\underline{\beta}(b)$ with $g(\beta)>0$ for all $\beta$ in $(\underline{\beta}(b), 1)$.

Equation (A.6) illustrates the trade-off. On the one hand, the higher future debt that a standstill generates relative to a write-off leads the sovereign to incur more deadweight costs of defaulting. This depresses future consumption and is represented by the second term in equation (A.6). When the fall in the bond price does not compensate for the higher sovereign borrowing, a standstill may enable the sovereign to consume more in the 
short-run $\left(c_{1}^{D S}(b)>c\left(b\left(1-\theta^{*}\right)\right)\right)$. However, when the sovereign is sufficiently patient, the potential short-run benefit of the standstills is offset by the future higher cost. Our quantitative analysis suggests that write-offs are more effective than standstills for empirically plausible discount factors.

Two final remarks are in order. First, notice that the result in Proposition 5 does not hinge on the presence of a debt overhang problem. The key feature is that standstills lead to more future debt and a lower market value of debt. Second, there are no income effects, and the model is silent about shocks to period-1 income. However, we do not think this is a critical limitation. A negative income "shock" in period 1 would have a similar effect to a lower discount factor $\beta$, as both increase the value of current vs. future consumption.

We show next that write-offs also dominate standstills when both policies are introduced at a time when the government does not have access to debt markets. It is worth mentioning that the ability to issue debt after a write-off is less beneficial to the sovereign in the two-period model than in the infinite-horizon one. Unlike in the infinite-horizon setup, in the two-period model, a write-off does not expand the borrowing set $q\left(b^{\prime}\right) b^{\prime}$.

\section{B.1 A two-period model with sudden stops}

The setup is the same as the one studied before with the exception that we let the cost of defaulting to have $[0, \infty)$ as support. Since the borrower cannot issue debt in period $1, b^{\prime}=b$ and the continuation value after repaying is

$$
V(b)=-\delta b-\beta[1-F(b)] b-\beta \int_{0}^{b} \phi f(\phi) d \phi .
$$

The equilibrium bond price is given by

$$
q(b)=1-F(b) .
$$

The continuation value under repayment with a standstill satisfies

$$
V^{D S}(b)=-\beta[1-F(b(1+\delta))] b(1+\delta)-\beta \int_{0}^{b(1+\delta)} \phi f(\phi) d \phi,
$$

and the bond price with a standstill satisfies

$$
q^{D S}(b)=[1-F(b(1+\delta))] .
$$

The next proposition shows that the borrower is better off and bondholders are worse off with a standstill. Proposition $6 V^{D S}(b)>V(b)$ and $q^{D S}(b)(1+\delta)<b[\delta+q(b)] \forall b>0$. 
Proof.

$$
\begin{aligned}
V(b)-V^{S}(b) & =-\delta b-\beta[1-F(b)] b-\beta \int_{-\infty}^{b} \phi f(\phi) d \phi+\beta[1-F(b(1+\delta))] b(1+\delta)+\beta \int_{-\infty}^{b(1+\delta)} \phi f(\phi) d \phi \\
& =-\delta b-\beta[1-F(b)] b+\beta[1-F(b(1+\delta))] b(1+\delta)+\beta \int_{b}^{b(1+\delta)} \phi f(\phi) d \phi \\
& \leq-\delta b-\beta[1-F(b)] b+\beta[1-F(b(1+\delta))] b(1+\delta)+\beta[F(b(1+\delta))-F(b)] b(1+\delta) \\
& \leq-\delta b-\beta F(b) b \delta+\beta b \delta \\
& \leq-\delta b[1-\beta(1-F(b))]<0,
\end{aligned}
$$

where the inequality stems from replacing $\int_{b}^{b(1+\delta)} \phi f(\phi) d \phi$ with $[F(b(1+\delta))-F(b)] b(1+\delta)$.

$$
\begin{aligned}
b[\delta+q(b)]-b(1+\delta) q^{D S}(b) & =b[\delta+1-F(b)]-b(1+\delta)[1-F(b(1+\delta))] \\
& =b[F(b(1+\delta))-F(b)+\delta F(b(1+\delta))]>0 .
\end{aligned}
$$

As in the model with borrowing, the borrower is better off with a standstill because it swaps a sure repayment in period 1 with a less-than-sure repayment in period 2 that is also discounted at the rate $\beta$. In the region where the government defaults with a standstill but repays without it, i.e., $\phi \in(b, b(1+\delta))$, the cost of defaulting is below $b(1+\delta)$. The value of debt claims at the beginning of period 1 declines with the standstill because the sure coupon payment $\delta$ is now exposed to default risk, and the higher debt carried to period 2 increases the default probability.

If the borrower receives a write-off that lowers its initial debt to $b(1-\theta)$, it is trivial to verify that $V(b(1-\theta))>$ $V(b)$. The effect on creditors' is less clear as $q(b(1-\theta))>q(b)$. The following proposition establishes that it is possible to find a write-off that strictly Pareto dominates the standstill.

Proposition 7 For any initial debt $b$, there is a $\underline{\beta}(b)$ such that for all $\beta \in[\underline{\beta}(b), 1]$, there exists a write-off that both the borrower and bondholders prefer over the standstill: $\forall b>0$, there is a $\theta^{*} \in(0,1)$ such that $V\left(b\left(1-\theta^{*}\right)\right)>V^{D S}(b)$ and $b\left[\delta+q\left(b\left(1-\theta^{*}\right)\right)\right]>b(1+\delta) q^{D S}(b)$.

Proof. Let $\underline{b}$ denote the lowest debt $b$ such that $\underline{b}(\delta+q(\underline{b}))=b(1+\delta) q^{D S}(b)$. It is easy to verify that $\underline{b}<b$. We will show there is a range of discount factors at which the borrower is strictly better off with $\underline{b}$ than with a standstill. 


$$
\begin{aligned}
V(\underline{b})-V^{D S}(b) & =-\delta \underline{b}-\beta[1-F(\underline{b})] \underline{b}-\beta \int_{-\infty}^{\underline{b}} \phi f(\phi) d \phi+\beta \underbrace{1-F(b(1+\delta))] b(1+\delta)}_{=q(\underline{b}) \underline{b}}+\beta \int_{-\infty}^{b(1+\delta)} \phi f(\phi) d \phi \\
& =-\delta \underline{b}-\beta[1-F(\underline{b})] \underline{b}+\beta \underline{b} \underbrace{\delta \delta+1-F(b)]}_{=q(\underline{b})}+\beta \int_{\underline{b}}^{b(1+\delta)} \phi f(\phi) d \phi \\
& =\delta \underline{b}(\beta-1)+\beta \int_{\underline{b}}^{b(1+\delta)} \phi f(\phi) d \phi .
\end{aligned}
$$

The expression in equation (A.7) is continuous, strictly increasing in $\beta$, takes a negative value at $\beta=0$, and a strictly positive value at $\beta=1$. Thus, there exists $\underline{\beta}(b) \in(0,1)$ such that $V(\underline{b}) \geq V^{S}(b)$ for $\beta \in[\underline{\beta}(b), 1]$. Notice that $q(b) b$ strictly increasing at $b=\underline{b}$, and the continuity of $V$ and $q(b) b$ implies that there exists a $b\left(1-\theta^{*}\right)>\underline{b}$ with the properties stated in the proposition.

Clearly, if $\beta=0$, there is no debt relief (other than with a write-off of 100 percent) that is better for the borrower than a delay in debt payments. However, for a high enough borrower's discount factor, it is possible to find write-offs that the borrower prefers over a standstill. This is the case because the write-off lowers the default probability and thus the deadweight cost of defaulting. At the same time, for bondholders, this lower default probability compensates the reduction in the face value of debt thus the debt value implied by the write-off in higher than the one implied by the standstill.

This result illustrates a key advantage of write-offs over standstills as instruments of debt relief. While standstills increase debt levels and thus the default probability and the expected deadweight cost of defaulting, write-offs reduce indebtedness and thus the default probability and the expected deadweight cost of defaulting. 